\title{
No More Secret Laws: How Transparency of Executive Branch Legal Policy Doesn't Let the Terrorists Win
}

Sudha Setty ${ }^{*}$

\author{
Inter arma enim silent leges. ${ }^{1}$ \\ (In times of war, the law falls silent.)
}

Whatever the general merits of the view that war silences law or modulates its voice, that view has no place in the interpretation and application of a Constitution designed precisely to confront war and, in a manner that accords with democratic principles, to accommodate it. ${ }^{2}$

\section{INTRODUCTION}

One of the key hallmarks of a democratic nation is that there are no secret laws. ${ }^{3}$ In the post-September 11, 2001 era, the George W. Bush administration relied on national security concerns and the unitary executive theory of presidential power as justifications for maintaining secret legal policies that govern parts of the war on terrorism that affect serious issues of human rights and civil liberties. These legal policies sometimes staked out positions that are at odds with legislation, treaties, and court decisions ${ }^{4}$ - but the parameters of the executive branch legal

\footnotetext{
* Assistant Professor of Law, Western New England College School of Law. A.B., Stanford University; J.D., Columbia Law School. I owe great thanks to those who discussed with me the ideas in this Article, or who reviewed and commented on drafts, including Jill Anderson, Erin Buzuvis, Matthew Charity, Robert Chesney, Kathleen Clark, Jamison Colburn, Anil Kalhan, Pratibha Kanive, Richard Kay, Gil Kujovich, Sylvia Lazos, Carol Liebman, Lance Liebman, Peter Margulies, Susan Martyn, Tayyab Mahmud, Bruce Miller, Trevor Morrison, Giovanna Shay, and James Wilson. I benefited greatly from the insight and commentary of participants at the 2008 MidAtlantic People of Color Legal Scholarship Conference, where I presented a draft of this paper Finally, my thanks to John Hejduk for his research assistance.

1. 14 Cicero, Pro T. Annio Milone Oratio, in Pro Milone-In Pisonem-Pro Scauro-Pro Fonteio-Pro Rabirio Postumo-Pro Marcello-Pro Ligario-Pro Rege Deiotario 16-17 (N.H. Watts trans., Harvard Univ. Press, 6th prtg. 1979).

2. Hamdi v. Rumsfeld, 542 U.S. 507, 579 (2004) (Scalia, J., dissenting).

3. See Lon L. Fuller, The Morality of LAW 39 (rev. ed. 1969) ("[T]he attempt to create and maintain a system of legal rules may miscarry [if there is] a failure to publicize, or at least to make available to the affected party, the rules he is expected to observe.").

4. See Jack M. Balkin \& Sanford Levinson, The Processes of Constitutional Change: From Partisan Entrenchment to the National Surveillance State, 75 FORDHAM L. REV. 489, 498 (2006) (noting that "[i]n many areas, the constitutional law enunciated in formal opinions and memoranda
} 
policies were sometimes unknown because of the lack of public disclosure. ${ }^{5}$ Administration critics decried the use of secret legal policy, and called for the disclosure of legal opinions generated by the Department of Justice Office of Legal Counsel. Some opinions were disclosed in the waning days of the Bush administration, others were disclosed early in the Obama administration, and still others remain unpublished and unknown.

This Article considers the call for disclosure and concludes that it is feasible, desirable, and realistic to expect the timely disclosure of most Office of Legal Counsel opinions. This Article recognizes the historical pattern of politicization of executive branch legal policy during a war or armed conflict, then analyzes how secrecy in the development and implementation of legal policy runs afoul of the rule of law, compromises the quality of legal policy being generated by the Office of Legal Counsel, and undermines public confidence in the integrity of executive branch constitutional interpretation. This Article uses both a historical and a comparative analysis to critique the use of secret law; first, by considering how the United States has historically dealt with the development of executive branch legal policy in wartime; second, by illustrating how other nations that face severe national security threats maintain greater transparency and accessibility for legal policy related to national security matters; and third, how the use of unitary executive theory to support nondisclosure is at odds with historical practice and the rule of law.

Part II outlines the history of the Office of the Attorney General and the Office of Legal Counsel, offers examples of the politicization of executive branch legal policy during times of conflict, and places in context the politicized opinions of the Office of Legal Counsel under the Bush administration.

Part III critiques the process by which the Office of Legal Counsel under the Bush administration developed, disseminated, and authorized legal policy without proper internal or external safeguards as to the quality of opinions being issued.

Part IV notes that scholars have promoted disclosure of executive branch legal policy as one of many potential means of countering the effects of a politicized environment within the Department of Justice. This part outlines the need for a general policy of disclosure in terms of

issued by the Office of Legal Counsel ... is sometimes at least as important as any decision of Article III courts").

5. See, e.g., Heidi Kitrosser, Congressional Oversight of National Security Activities: Improving Information Funnels, 29 CARDOZO L. REV. 1049, 1055 (2008). 
increasing the quality of the opinions issued, curbing the greatest excesses of the secret opinions, and asserts the need for a new mandatory disclosure requirement for future administrations.

Part V addresses whether a call for disclosure is workable in light of two typical rebuttals offered by U.S. administrations: the pragmatic argument that secrecy and non-disclosure are necessary to maintain the integrity of the national security efforts, and that the lack of disclosure is consistent with the President's powers, particularly during wartime. This part critiques both of those arguments in favor of secret law, based on Congress's constitutional powers for oversight of the Executive, historical practices of the United States, as well as a comparative analysis with India, Israel, and the United Kingdom.

\section{The Politicization OF THE OFFICE OF THE ATtORNEY GENERAL}

One of the fundamental responsibilities of the U.S. Attorney General and his or her subordinates in the Office of Legal Counsel is to provide legal advice and counsel to the administration. ${ }^{6}$ As the chief legal officer of the United States, the Attorney General has an obligation to uphold the rule of law by providing the best possible legal counsel to the President and administration and to limit the effect of political pressures to mold his or her opinion to facilitate the political goals of the President. ${ }^{7}$ The importance of adhering to the rule of law is compounded when the legal opinions offered by the Attorney General are used as legal comfort - protecting government actors from future liability and criminal prosecution while conducting work on behalf of the administration. ${ }^{8}$

6. Nancy V. Baker, Conflicting Loyalties: Law and Politics in the Attorney General's OfFICE, 1789-1990, at 1-2 (1992); see Dawn E. Johnsen, Faithfully Executing the Laws: Internal Legal Constraints on Executive Power, 54 UCLA L. REV. 1559, 1577 (2007) (noting that the opinions generated by the Office of Legal Counsel are generally considered binding on the executive branch, unless the President or Attorney General disagrees based on a differing legal interpretation).

7. Kathleen Clark, Ethical Issues Raised by the OLC Torture Memorandum, 1 J. NAT'L SEC. LAW \& POL'Y 455, 464-66 (2005) ("When a lawyer gives legal advice ... she has a professional obligation of candor toward her client.... [T] he lawyer's role is not simply to spin out creative legal arguments. It is to offer her assessment of the law as objectively as possible." (citing MODEL RULES OF PROF'L CONDUCT R. 2.1 (2003))). Clark contrasts this obligation of a legal advisor to offer his or her "best assessment" of the law with that of a legal advocate, who can offer any nonfrivolous interpretation of the law when arguing on behalf of a client before a judge. Id. at 465; see also Oversight of the Department of Justice: Hearing Before the S. Comm. on the Judiciary, 110th Cong. 55 (2008) [hereinafter Oversight Hearing Transcript] (statement of Sen. Whitehouse) (noting that the Attorney General has "assumed the role, in essence, of, sort of, a corporate counsel to the executive branch").

8. JaCK Goldsmith, The Terror Presidency: LaW and Judgment Inside the Bush ADMINISTRATION 96 (2007) (quoting a senior Justice Department prosecutor noting that it is 
However, numerous obstacles exist to the Office of Legal Counsel offering its most impartial, and arguably best, assessment of the law, including the inherent conflicts of interest which arise when the administration attempts to influence the Office of Legal Counsel to issue opinions that are politically advantageous to the administration. ${ }^{9}$ Historically, this political pressure has been brought to bear during times of war or armed conflict, raising doubts as to whether any administration can achieve the "best practice" of offering non-politicized legal advice at all times. ${ }^{10}$

\section{A. The Roles of the Attorney General and the Office of Legal Counsel}

The history of the roles of the Attorney General and the Office of Legal Counsel provide insight into the pattern of politicization of these offices in wartime.

The role of Attorney General has existed since prior to the inception of the federal government, ${ }^{11}$ having been modeled after the English governmental system and the colonial state governments in America, ${ }^{12}$ and was established at the federal level by the Judiciary Act of $1789 .{ }^{13}$ In enacting the Judiciary Act, Congress and the President delegated executive branch constitutional interpretation to the Office of the Attorney General. ${ }^{14}$

The tension between the Attorney General's dual obligations - on the one hand to render the highest quality legal advice possible to the President, and on the other hand to offer politically advantageous opinions to the President-has existed from the very beginning of the office in the U.S. federal system. ${ }^{15}$ President Washington made it clear to Edmund Randolph, the first U.S. Attorney General, that he wanted the Attorney General to be "a skilled, neutral expounder of the law rather

\footnotetext{
"“practically impossible to prosecute someone who relied in good faith on an [Office of Legal Counsel] opinion, even if the opinion turns out to be wrong"').

9. Clark, supra note 7, at 464-65.

10. See, e.g., GolDSMITH, supra note 8, at 34-35 (noting that the OLC should offer opinions that strike a balance between a neutral exposition of the law and client advocacy on behalf of the administration's desired result); Walter Dellinger et al., Principles to Guide the Office of Legal Counsel (2004), reprinted in Johnsen, supra note 6, app. 2 at 1603-04 (calling for the OLC to maintain a non-politicized stance in developing legal policy).

11. BAKER, supra note 6 , at 37 .

12. Id. at $37-38$.

13. Judiciary Act of 1789 , ch. $20, \S 35,1$ Stat. 73,93 (codified as amended at 28 U.S.C. $\S 511$ (2006)).

14. GOLDSMITH, supra note 8 , at 32 .

15. BAKER, supra note 6 , at 55 .
} 
than a political advisor."16 In response, Randolph wrote to Washington in 1794 , shortly after the end of his term in office:

$[\mathrm{M}] \mathrm{y}$ opinions, not containing any systematic adherence to party, but arising solely from my views of right, fall sometimes on one side and sometimes on the other.... [W] hile I retain a consciousness of my ability to resist an undue influence, I cannot deny the satisfaction which I feel in maintaining [my reasoning].... I have often indeed expressed sentiments contrary to yours. This was my duty; because they were my sentiments. But, Sir, they were never tinctured by any other motive, than to present to your reflection the misconstructions which wicked men might make of your views, and to hold out to you a truth of infinite importance to the United States ....

Although the Attorney General originally served as a counselor to both the President and to Congress, ${ }^{18}$ the Attorney General and the Department of Justice are now understood to be firmly within the auspices of the executive branch. ${ }^{19}$

The Office of Legal Counsel, generally referred to as the OLC, has been in existence since 1933 as part of the Department of Justice. ${ }^{20}$ Its role is to provide legal advice on the actions of all of the administrative departments that report to the President: it makes a determination on whether proposed actions and programs are illegal or unconstitutional, and provides advice to the President as to whether programs should be cancelled or modified due to legal constraints. ${ }^{21}$ In fact, the OLC

16. Griffin B. Bell, Office of Attorney General's Client Relationship, 36 Bus. Law. 791, 791 (1981).

17. Letter from Edmond Randolph to George Washington (Apr. 19, 1794), in MONCURE DANiEl CONWAy, OMitTed Chapters OF History Disclosed IN THE LifE AND PAPERS OF EDMUND RANDOLPH 218-19 (1888).

18. In large part, the Office of the Attorney General and its role in government were not given a close examination at the time they were adopted into the U.S. federal system - it was simply understood that the President and Congress required legal counsel, and that the Attorney General could provide the necessary advice to both of the political branches of government. BAKER, supra note 6 , at 15 .

19. Id. at 16,59 . Nonetheless, some argue that there remains a residual tension as to how much information the Attorney General is obligated to disclose to Congress, particularly with regard to the legal policy developed and implemented by the executive branch. Id. at 10-11. Baker notes a second tension arising from the Attorney General's role as counselor to the administration and his or her role as an officer of the court. Id. at 2, 22-25.

20. Id. at $10-11$.

21. GoldSMith, supra note 8, at 32; see also Office of Legal Counsel Homepage, http:// www.usdoj.gov/olc (last visited Apr. 11, 2008) (noting that the OLC "is responsible for providing legal advice to the executive branch on all constitutional questions"). The client of the OLC, as with the Attorney General, is generally understood to be the administration as a whole. See BAKER, supra note 6, at 10-11. This sets the OLC apart from the Office of the White House Counsel-a presidential appointee who serves as the President's personal counsel and adviser. See generally Maryanne Borrelli et al., The White House Counsel's Office, 31 Presidential STUD. Q. 561 (2001), 
"renders all but a small portion of the formal legal opinions of the Department of Justice." 22 The head of the OLC reports to the Attorney General. $^{23}$

The OLC has been viewed historically as the first line of defense against self-serving legal interpretation by the executive branch. ${ }^{24}$ However, as the OLC is obligated to respond to real-time legal questions, the danger of politicization or other undermining of the integrity of the opinions becomes pressing: there are few mandated external controls over the OLC, no oversight outside the direct chain of command in the administration, and no public accountability for the legal policy being developed and relied upon. ${ }^{25}$ Over the years, the OLC has avoided some of the pitfalls that exist from a lack of accountability by operating under strong cultural norms of apoliticism. ${ }^{26}$ However, that culture has not always been maintained, both in the $\mathrm{OLC}^{27}$ and in the Justice Department as a whole.

\section{B. Historical Examples of the Attorney General Facilitating the Accrual of Presidential Power}

This tension is often dormant, and the public becomes aware of its existence only when it flares up; for example, when the Attorney General or the OLC offers an opinion based primarily on political exigency, ${ }^{28}$ as opposed to balancing the interests of the administration and the obligation to give sound legal advice. ${ }^{29}$

available at $\mathrm{http}: / /$ findarticles.com/p/articles/mi hb6387/is /ai n25554509.

22. Randolph D. Moss, Executive Branch Legal Interpretation: A Perspective from the Office of Legal Counsel, 52 ADMIN. L. REV. 1303, 1308 (2000).

23. See 28 U.S.C. $\S 510$ (2000) (codifying the right of the Attorney General to delegate the responsibility to draft legal opinions to the OLC); $\S \S 511-513$ (delineating the Attorney General's authority to render legal opinions to the President and executive branch); see also 28 C.F.R. $\S 0.25$ (2008) (describing matters assigned to the Assistant Attorney General); GOLDSMITH, supra note 8, at 32 (describing the trend of recent Attorneys General delegating the legal advisory function to OLC).

24. See GoldSMITH, supra note 8, at 33 .

25. Id.

26. See id.

27. See Cornell W. Clayton, The Politics of Justice: The Attorney General and the MAKING OF LEGAL POLICY 34 (Stephen J. Wayne, ed., 1992) (arguing that because the OLC is asked to develop legal policies that support administration goals, it is often viewed as one of the most politicized units within the Department of Justice).

28. I am referring to the interests of an administration based on political needs, not necessarily influenced by partisan politics.

29. See Sam J. Ervin, JR., The Whole Truth: The Watergate Conspiracy 118-19 (1980) (discussing the public belief that the Department of Justice was wholly politicized in its rendering of legal opinions for President Richard Nixon). 
As with the George $\mathrm{W}$. Bush administration, this tension consistently occurs during a war or other military conflict when a President believes that he can and should assert greater executive power under the Commander-in-Chief clause ${ }^{30}$ to respond appropriately to wartime crises. ${ }^{31}$ Controversial examples of this type of wartime action are found throughout U.S. history, and two such examples illustrate the same tension that existed in the Bush administration.

The first is the legal comfort offered by Abraham Lincoln's Attorney General, Edward Bates, to authorize the suspension of the writ of habeas corpus for Confederate soldiers during the Civil War. ${ }^{32}$ This was a decision that Bates made reluctantly in order to support Lincoln's already articulated war strategy. ${ }^{33}$ Bates set aside his misgivings about the legality of the suspension of the writ to support the President's Civil War strategy, ${ }^{34}$ authoring an opinion that acknowledged both the right of the court to issue a writ of habeas corpus, as the well as the President's right to refuse to obey such a writ. ${ }^{35}$

To gain support for his war plan, Lincoln heavily publicized his belief that the suspension of the writ of habeas corpus was necessary to the Union Army's wartime efforts. ${ }^{36}$ There is no doubt that Lincoln consolidated and increased presidential power in response to the exigencies of war, and that the decision to suspend the writ of habeas corpus was part of that effort; ${ }^{37}$ there is also no doubt that Lincoln's efforts were well-known and his shift in legal policy was subject to

30. U.S. CONST. art. II, § 2, cl. 1.

31. See Johnsen, supra note 6, at 1560 ("President Bush and his lawyers have espoused an extreme view of expansive presidential power during times of war and national emergency, a view that draws especially on the President's constitutional role as commander-in-chief.").

32. Bates' opinion was issued on July 5, 1861. J. FrankLIN JAMESON, Dictionary of UNITED STATES HISTORY: 1492-1895, at 284 (1894). Lincoln ordered the arrest and detention of Confederate soldiers in April of 1861, see Abraham Lincoln, Executive Order to the Commanding General of the Army of the United States (Apr. 27, 1861), in 7 A COMPILATION OF THE MESSAGES AND PAPERS OF THE PRESIDENTS, 1784-1897, at 3219 (James D. Richardson ed., 1897) [hereinafter MESSAGES AND PAPERS], making clear that although Bates' opinion was valuable to Lincoln, it was not the decisive opinion on whether to suspend the writ. Peter Margulies, True Believers at Law: National Security Agendas, the Regulation of Lawyers, and the Separation of Powers, 68 MD. L. Rev. 1, 71-73 (2008); see also David J. Barron \& Martin S. Lederman, The Commander in Chief at its Lowest Ebb: A Constitutional History, 121 HARV. L. REV. 941, 998-1000 (2008).

33. BAKER, supra note 6 , at 3 .

34. Id.

35. CLAYTON, supra note 27, at 20.

36. The most notable effort was Lincoln's July 4, 1861 address to Congress, in which he argued that the suspension of the writ of habeas corpus was necessary to preserve the nation. See Abraham Lincoln, Special Session Message (July 4, 1861), in 7 MeSSAGES AND PAPERS, supra note 32, at 3226-27.

37. ARTHUR M. SCHLESINGER, JR., WAR AND the AMERICAN PRESIDENCY 50-51 (2004). 
significant public scrutiny. ${ }^{38}$ Further, as a result of the publicity, efforts to build a consensus, public support, and congressional concern over the war, Congress passed resolutions in support of the suspension of the writ of habeas corpus for Confederate soldiers. ${ }^{39}$

A second example in which the "best assessment" of legal counsel was subsumed by political interests was the decision by Francis Biddle, Franklin Roosevelt's Attorney General, to acquiesce to the internment of Japanese Americans during World War II under Roosevelt's war-making powers as President. ${ }^{40}$ Although evidence suggests that the decision to offer legal comfort for the internment was made against Biddle's judgment as to the best interpretation of the law, ${ }^{41}$ and perhaps even against his judgment as to a morally or legally defensible argument, Biddle reconciled himself to supporting Roosevelt's plan to intern Japanese Americans to alleviate perceived national security concerns. ${ }^{42}$ Roosevelt, like Lincoln nearly a century before, publicized his decision and rallied public support for the measure. ${ }^{43}$ In fact, Congress supported

38. GOLDSMITH, supra note 8 , at $82-83$.

39. JAMESON, supra note 32, at 284. Lincoln's desire to suspend the writ of habeas corpus was met with strident opposition from Roger B. Taney, Chief Justice of the U.S. Supreme Court. In $E x$ parte Merryman, Taney denied the right of the President to suspend the writ, with Taney offering the following indictment of Lincoln's attempt to, in Taney's view, subvert the rule of law:

These great and fundamental laws, which congress itself could not suspend, have been disregarded and suspended, like the writ of habeas corpus, by a military order, supported by force of arms.... I can only say that if the authority which the constitution has confided to the judiciary department and judicial officers, may thus, upon any pretext or under any circumstances, be usurped by the military power, at its discretion, the people of the United States are no longer living under a government of laws, but every citizen holds life, liberty and property at the will and pleasure of the army officer in whose military district he may happen to be found.

17 F. Cas. 144, 152 (C.C.D. Md. 1861) (No. 9487). Later, the Court authorized the suspension of the writ of habeas corpus during the Civil War, for the limited context of when Confederate soldiers were captured but civilian courts were fully closed. See generally Ex parte Milligan, 71 U.S. (4 Wall.) 2 (1866).

40. See Exec. Order No. 9066, 7 Fed. Reg. 1407 (Feb. 19, 1942) (allowing for the internment of Japanese and Japanese American people due to national security concerns). See generally COMM'N on Wartime Relocation \& Internment of Civilians, Personal Justice Denied (1982). Biddle's advice was later validated by the U.S. Supreme Court in Korematsu v. United States, 323 U.S. 214 (1944) (holding that the decision of President Roosevelt to intern Japanese Americans during World War II was consistent with the President's war powers).

41. See SCHLESINGER, supra note 37, at 56 (noting that Biddle opposed the internment of Japanese Americans).

42. See BAKER, supra note 6, at 34 (arguing Biddle "questioned the constitutionality of interning those who were U.S. citizens" but still acquiesced).

43. See Peter Margulies, When to Push the Envelope: Legal Ethics, the Rule of Law, and National Security Strategy, 30 FORDHAM INT'L L.J. 642, 651 (noting that the legal defense of internment "hinged on a stereotype of Japanese-Americans as insidious and inscrutable security risks" and that government lawyers appealed to the court's acceptance of "the discrimination that Japanese-Americans had frequently faced in the United States"). In 1982, the congressionally 
the President's decision, ${ }^{44}$ and the constitutionality of the internment was validated in 1944 by the U.S. Supreme Court in Korematsu v. United States. $^{45}$

In the cases of Bates and Biddle, the politicization of the Office of the Attorney General occurred in a time of great national tension, when the President was exercising his wartime powers. Although the justifications for offering legal comfort may in retrospect seem tenuous at best ${ }^{46}$ the fact that the decision-making was made public and in consultation with Congress allowed for some measure of public confidence in the making of executive branch legal policy, ${ }^{47}$ and, perhaps more importantly, the opportunity for public scrutiny to force changes in bad policy. ${ }^{48}$

charged Commission on Wartime Relocation and Internment of Civilians concluded that there was no military necessity for internment; rather, it was a product of wider societal and governmental problems including "race prejudice, war hysteria and a failure of political leadership." ERIC K. YAMAMATO ET AL., RACE, RightS AND REPARATION: LAW AND THE JAPANESE AMERICAN INTERNMENT 40 (2001).

Scholars have noted that Roosevelt's ability to rally public, congressional and judicial support for his wartime policies cemented the perceived need for executive flexibility in carrying out controversial policies in times of emergency. See Kim Lane Scheppele, Small Emergencies, 40 GA. L. REV. 835, 850-51 (2006) (concluding that "[e]mergency powers had been given a judicial stamp of approval" and that "Congress continued to cede powers to Roosevelt, but often after Roosevelt's impassioned public addresses threatened to seize the power").

44. Congress validated Executive Order No. 9066 explicitly by making it a misdemeanor to disregard the Order's curfew and movement restrictions. Act of Mar. 21, 1942, ch. 191, 56 Stat. 173; see also Hirabayashi v. United States, 320 U.S. 81 (1943) (validating the curfew requirements of the 1942 Act).

45. 323 U.S. 214 (1944). Korematsu's conviction for being found outside of an exclusionary zone for persons of Japanese descent was overturned in 1984. Korematsu v. United States, 584 F. Supp. 1406 (N.D. Cal. 1984). Judge Patel, in overturning the conviction, noted that "[f]ortunately, there are few instances in our judicial history when courts have been called upon to undo such profound and publicly acknowledged injustice." Id. at 1413.

46. In contrast, other administrations have leveraged the fact that the Department of Justice, unlike other administrative agencies, has no particular industry or special interest group to answer to and is, therefore, most prone to unilateral presidential control. See Clayton, supra note 27, at 7778 (noting that President Nixon exercised a great deal of control over the Department of Justice).

47. Johnsen, supra note 6, at 1590 (noting that when President Ronald Reagan wanted to put forth a different constitutional provision than had previously been used by Congress and the judiciary, he made that debate public). Publicity, however, does not guarantee accountability. In the case of the suspension of the writ of habeas corpus, the judiciary attempted to check President Lincoln's actions. See Ex parte Merryman, 17 F. Cas. 144 (C.C.D. Md. 1861) (No. 9487) (denying the right of the President to suspend the writ). President Lincoln chose not to comply with regard to Confederate soldiers taken prisoner by Union forces. BAKER, supra note 6, at 20.

48. In contrast, the legal advice offered during the presidency of Richard Nixon has been criticized both for substance and the secrecy in which it was shrouded. See United States v. Nixon, 418 U.S. 683, 703-07 (1974) (accepting the idea of a broad deliberative privilege for a President, but rejecting the right of executive branch constitutional interpretation to trump that of the judiciary); see also Oversight Hearing Transcript, supra note 7, at 2. Sen. Patrick Leahy commented to Attorney General Michael Mukasey:

I first came to the Senate 33 years ago. The nation and the Department of Justice were 


\section{Current Examples of the Politicization of the Office of Legal Counsel}

During the years of the George W. Bush administration, the Office of Legal Counsel drafted numerous memoranda and legal opinions that engendered a great deal of criticism on two fronts: first, for the substance of the policies promulgated. ${ }^{49}$ As with the examples of Bates and Biddle, one criticism of the OLC is that its legal advice facilitates a vast expansion of presidential power. The second body of criticism stems from the process by which the OLC developed and implemented its legal policy. ${ }^{50}$ In sharp contrast to the Bates and Biddle examples, the primary concern here is the secretive process by which legal policy is developed and implemented. ${ }^{51}$

In fact, the Bush administration's concerted effort to cut the judiciary and Congress out of the decision-making process on legal policy is the antithesis of the approach undertaken by the Lincoln and Roosevelt administrations. ${ }^{52}$ Although issues of war and armed conflict have affected many administrations, when executive branch legal policy is not

reeling from Watergate. The trust of the American people in their government had been shaken. The damage done over the last seven years to our constitutional democracy and our civil liberties rival the worst of those dark days. This president's administration has repeatedly ignored the checks and balances that have been wisely placed on executive power by our founders .... [A]mong the most disturbing aspects of those years has been the complicity of the Justice Department, which has provided cover for the worst of these practices during those seven years.

Id.

49. See Clark, supra note 7, at 458-63 (arguing that the U.S. Government relied on inaccurate statements of law in setting interrogation policies); Patricia Mell, Big Brother at the Door: Balancing National Security with Privacy Under the USA PATRIOT Act, 80 DENV. U. L. Rev. 375, 379-80 (2002) (addressing the effects of the PATRIOT Act on individual privacy rights); Beth Stephens, Upsetting Checks and Balances: The Bush Administration's Efforts to Limit Human Rights Litigation, 17 HARV. HUM. RTS. J. 169, 182 (2004) (documenting the attempts of the George W. Bush administration to curtail judicial review in cases of alleged human rights violations by the U.S. government).

50. See generally GoldSMITH, supra note 8 (examining the "role that lawyers played in determining counterterrorism policy"); Johnsen, supra note 6 (advocating the need for internal legal constraints in the executive branch); Trevor W. Morrison, Constitutional Avoidance in the Executive Branch, 106 COLuM. L. REV. 1189, 1250-58 (2006) (noting the executive branch's use of constitutional avoidance theory to assert its right to circumvent the parameters of FISA); $\mathrm{H}$. Jefferson Powell, The Executive and the Avoidance Canon, 81 IND. L.J. 1313 (2006) (arguing the avoidance canon should not be used on issues regarding the separation of powers between Congress and the President).

51. SCHLESINGER, supra note 37, at 61 (concluding that the last Bush administration was the most secretive in U.S. history, including the Nixon administration); Scott Shane et al., Secret U.S. Endorsement of Severe Interrogation, N.Y. TIMES, Oct. 4, 2007, at A1 (noting that the last Bush administration adapted new legal policies on interrogation "without public debate or Congressional vote, choosing to rely instead on the confidential legal advice of a handful of appointees").

52. See GoldSMith, supra note 8, at 82-85; Jeffrey Rosen, Conscience of a Conservative, N.Y. Times MAgaZine, Sept. 9, 2007, at 40, 45. 
disclosed in a meaningful fashion to other parts of the administration, the other branches of the federal government, or to the public, it is clear that the quality of the legal policy, as well as the credibility of the administration's lawyers, suffers greatly.

A number of examples of controversial and secret legal opinions evidence the Bush administration's expansive view of presidential powers vis-à-vis the war on terror, and the intense interest in excluding Congress, the public, and even other departments within the executive branch $^{53}$ from understanding the parameters of executive branch legal policy. ${ }^{54}$

First, two August 2002 OLC memoranda (the "Bybee Memoranda") analyzed the definition of "torture" with regard to interrogation techniques used on persons captured in the war on terror and held outside of the United States. The first memorandum ${ }^{55}$ was drafted by OLC attorney John Yoo $^{56}$ and signed by Assistant Attorney General Jay Bybee. Although the administration relied on this memorandum since 2002 to delineate those interrogation techniques that were arguably lawful, ${ }^{57}$ the memorandum itself was only made public after it was

53. Not every OLC opinion related to national security matters was insulated from other administrative departments. E.g., Memorandum from William H. Taft, IV, Legal Adviser, U.S. Dep't of State, to John C. Yoo, Deputy Assistant Att'y Gen., U.S. Dep't of Justice (Jan. 11, 2002), available at https://www.pegc.us/archive/State_Department/taft_memo20020111.pdf. In a cover letter accompaning a forty-page critique of an $\mathrm{OL} C \mathrm{C}$ draft memorandum regarding detainee treatment, Taft notes that "both the most important factual assumptions on which [Yoo's] draft is based and its legal analysis are seriously flawed." Id. at 1; see also M. Elizabeth Magill, Can Process Cure Substance? A Response to Neal Katyal's "Internal Separation of Powers," 116 YALE L.J. PocKeT PART 126, 130 (2006) (stating that the last Bush administration was aware of opposing arguments but disagreed with them).

54. The concern about secret laws and rules developed by the last Bush administration extends beyond the OLC. See, e.g., Bruce Ackerman, Take Your Paws off the Presidency!, Slate, July 15, 2008, http://www.slate.com/id/2195384index.html (discussing the possibility of secret executive orders in place that would alter the presidential succession process notwithstanding constitutional and congressional constraints).

55. Memorandum from Jay S. Bybee, Assistant Att'y Gen., U.S. Dep't of Justice Office of Legal Counsel, to Alberto R. Gonzales, Counsel to the President (Aug. 1, 2002) [hereinafter Bybee Memorandum]. The Bybee Memorandum was superseded, in part, by another memorandum drafted by the acting head of the OLC, Daniel Levin, that addressed the applicability of the Convention Against Torture and disavowed some of the conclusions made in the Bybee Memorandum. See Memorandum from Daniel Levin, Acting Assistant Att'y Gen., U.S. Dep't of Justice Office of Legal Counsel, to James B. Comey, Deputy Att'y Gen. (Dec. 30, 2004) [hereinafter Levin Memorandum].

56. John Yoo, Behind the 'Torture Memos,' SAN Jose Mercury News, Jan. 2, 2005, at 1P (acknowledging that he helped to draft the Bybee Memorandum).

57. The Defense Department incorporated significant portions of the language from the Bybee Memorandum in its own report on interrogation practices. See U.S. DEP'T OF DEF., WORKING GROUP REPORT ON DETAINEE INTERROGATIONS IN THE GLOBAL WAR ON TERRORISM 61-69 (2003) (enumerating thirty-five techniques and evaluating the usefulness of those techniques); see also Douglas Jehl et al., C.I.A. Is Seen as Seeking New Role on Detainees: Officials Say Agency Is Fearful of Blame, N.Y. TimES, Feb. 16, 2005, at A16 (explaining that the Bybee Memorandum was 
leaked in mid-2004 after the public learned of detainee abuses at the Abu Ghraib prison in Iraq. ${ }^{58}$ At that point, congressional and public outrage at the content of the memorandum, ${ }^{59}$ which authorized the use of harsh interrogation techniques and narrowed the conventional definition of torture $^{60}$ to provide legal comfort to interrogators who engaged in harsh techniques, ${ }^{61}$ forced the President to disavow the use of torture during interrogations. ${ }^{62}$

The second August 2002 memorandum-issued on the same day as the first and also authorized by Bybee ${ }^{63}$ - reinforced the administration's view that the definition of torture was extremely narrow and required specific intent by interrogators to cause serious physical or mental harm,

"sought by the C.I.A. to protect its employees from liability").

58. See Dana Priest \& R. Jeffrey Smith, Memo Offered Justification for Use of Torture, WASH. Post, June 8, 2004, at A1 ("[T]he Justice Department advised the White House that torturing alQaeda terrorists in captivity abroad 'may be justified,' and that international laws against torture 'may be unconstitutional if applied to interrogations' conducted in President Bush's war on terrorism."); see also From the Department of Justice to Guantanamo Bay: Administration Lawyers and Administration Interrogation Rules, Part III: Before the Subcomm. on the Constitution, Civil Rights, and Civil Liberties of the H. Comm. on the Judiciary, 110th Cong. 2 (2008) [hereinafter Interrogation Rules, Schroeder Statement], available at http://judiciary.house.gov/hearings/pdf/ Schroeder080626.pdf (statement of Christopher H. Schroeder, Professor of Law \& Pub. Pol'y Stud., Duke Univ.) ("[T]o this day, we might not know of the existence of this memo had it not been leaked around the time that the photographs from Abu Ghraib were being exposed."). A contemporaneous OLC memorandum on interrogation techniques remains secret from the public. Id. at 3 .

59. See Adam Liptak, Legal Scholars Criticize Memos on Torture, N.Y. TIMES, June 25, 2004, at A14 ("[A] law professor at the University of Chicago said: 'It's egregiously bad. It's very low level, it's very weak, embarrassingly weak, just short of reckless.”'). Compare Posting of Jack Balkin to Balkinization, Arguments That Make You Ashamed to be a Lawyer, http:// balkin.blogspot.com/2004/06/arguments-that-make-you-ashamed-to-be.html (June 9, 2004, 12:14 EST) ("The torture memo ... makes the President a King, someone who must be presumed to do no wrong. If the President adopted this position, and acted upon it, it would be grounds for impeachment."), with Adrian Vermeule \& Eric A. Posner, A 'Torture' Memo and Its Tortuous Critics, WALL ST. J., July 6, 2004, at A22 (arguing that the Bybee Memorandum "falls well within the bounds of professionally respectable argument").

60. Bybee Memorandum, supra note 55, at 46 (" $[\mathrm{W}] \mathrm{e}$ conclude that torture as defined in and proscribed by [the Convention Against Torture] covers only extreme acts.... Because the acts inflicting torture are extreme, there is [a] significant range of acts that though they might constitute cruel, inhuman, or degrading treatment or punishment fail to rise to the level of torture."). The Bybee Memorandum also stated that the proscriptions of the Convention Against Torture likely did not apply to the President's execution of the war on terror, under the rationale that the Convention infringed upon the President's executive authority as Commander-in-Chief. See id. at 36-39 (“[T]he structure of the Constitution demonstrates that any power traditionally understood as pertaining to the executive-which includes the conduct of warfare and the defense of the nation-unless expressly assigned in the Consitution to Congress, is vested in the President.").

61. Additionally, Bybee offered two broad defenses to individuals who used techniques which would fall within the narrowed definition of torture: necessity and self-defense. Id. at 39-46.

62. Eric Mink, Editorial, The Torture Memos, St. Louis Post-DisPatch, Apr. 9, 2008, at D11. See generally Shane et al., supra note 51, at A1; Levin Memorandum, supra note 55.

63. Memorandum from Jay S. Bybee, Assistant Att'y General, U.S. Dep't of Justice Office of Legal Counsel (Aug. 1, 2002) [hereinafter Second Bybee Memorandum]. 
and that interrogators were protected from future prosecution because they had no such specific intent. ${ }^{64}$ A heavily redacted version of this memorandum was released by the administration on July 24, 2008, in response to a Freedom of Information Act (FOIA) request from the American Civil Liberties Union. ${ }^{65}$

Tellingly, only the late 2004 OLC memorandum declaring that " "torture is abhorrent both to American law and values and to international norms" "was voluntarily made public by the administration. ${ }^{66}$ However, even this memorandum contained legal protection for CIA interrogators to reassure them that past practices were not prosecutable. ${ }^{67}$

Second, a 2002 executive order issued by President Bush $^{68}$ authorized the National Security Agency to conduct warrantless surveillance programs over U.S. citizens, which were authorized by the OLC $^{69}$ but not revealed to the judiciary, including the Foreign Intelligence Surveillance Act (FISA) ${ }^{70}$ court. $^{71}$ This executive order was not disclosed until late 2005, at which point Congress immediately demanded to be briefed on the program to understand its parameters. ${ }^{72}$

64. Id. at $16-17$.

65. See American Civil Liberties Union, Documents Released by the CIA and Justice Department in Response to the ACLU's Torture FOIA (July 24, 2008), http://www.aclu.org/ safefree/torture/36104res20080724.html.

66. Shane et al., supra note 51.

67. Id.; Levin Memorandum, supra note 55, at 17.

68. James Risen \& Eric Lichtblau, Bush Lets U.S. Spy on Callers Without Courts, N.Y. TIMES, Dec. 16, 2005, at A1.

69. Jack Goldsmith stated that the White House systematically undermined FISA protections using secret and "flimsy" legal opinions which were "guarded closely so no one could question the legal basis for the operations." Rosen, supra note 52, at 45 . The OLC has also opined that Fourth Amendment protections against unlawful search and seizure do not apply to "domestic military operations." Memorandum from John C. Yoo, Deputy Assistant Att'y Gen., to William J. Haynes II, Gen. Counsel of the Dep't of Def. 8 n.10 (Mar. 14, 2003) [hereinafter Yoo Memorandum] (referring back to an earlier, still-secret OLC memorandum entitled, "Authority for Use of Military Force to Combat Terrorist Activities Within the United States").

70. The Foreign Intelligence Surveillance Act, 50 U.S.C. $\S \S 1801-1863,1871$ (2000).

71. See Risen \& Lichtblau, supra note 68.

72. See Oversight Hearing Transcript, supra note 7, at 4 (disagreeing with the President's view that warrantless wiretapping is within the President's inherent executive authority, and arguing that the President cannot be above the rule of law); Scott Shane \& Eric Lichtblau, Full House Committee Gets Briefing on Eavesdropping, N.Y. TIMES, Feb. 9, 2006, at A22; Charles Babington, White House Agrees to Brief Congress on NSA Surveillance, WASH. POST, Feb. 9, 2006, at A6; Nancy Pelosi, Editorial, The Gap in Intelligence Oversight, WASH. POST, Jan. 15, 2006, at B7; Memorandum from Alberto R. Gonzales, Att'y Gen., to William H. Frist, Majority Leader, U.S. Senate 1-3, 6-36 (Jan. 19, 2006), available at http://www.usdoj.gov/opa/whitepaperonnsalegalauthorities.pdf. For a detailed analysis of the legality of the NSA wiretapping program, see generally John Cary Sims, What NSA Is Doing . . and Why It's Illegal, 33 HASTINGS CONST. L.Q. 105 (2006). 
Third, a March 2003 memorandum authored by Yoo (the "Yoo Memorandum" $)^{73}$ provided additional legal comfort to interrogators by asserting that "federal laws prohibiting assault, maiming and other [violent] crimes did not apply to military interrogators" who questioned captives in the war on terror, based on the President's wartime powers. ${ }^{74}$

The Yoo Memorandum sought to insulate U.S. government agents from prosecution or other legal liability if they used highly coercive interrogation techniques, such as waterboarding, head-slapping, and exposure of prisoners to extreme temperatures. ${ }^{75}$

The existence of this memorandum had been known outside of the administration for several years, despite the administration's refusal to disclose it to the public or most members of Congress until April 1, $2008 .^{76}$ The memorandum was initially classified by the Department of Justice to prevent disclosure, but was ultimately declassified after a review undertaken as part of a Freedom of Information Act lawsuit brought by the American Civil Liberties Union to gain access to the memorandum. ${ }^{77}$

The initial classification of the Yoo Memorandum was made because of purported national security concerns associated with the release of the opinion; ${ }^{78}$ remarkably, however, the contents of the Yoo Memorandum were kept secret from the top lawyers for each branch of the military. ${ }^{79}$ Since the public release of the Yoo Memorandum, scholars have questioned why such an opinion-containing no sensitive personal information nor details about specific intelligence-gathering programswas ever withheld from public view. ${ }^{80}$

Fourth, a 2005 opinion authorized harsh techniques, such as waterboarding, and the use of such techniques in combination with each other, for the interrogation of persons designated as enemy combatants. ${ }^{81}$ This opinion was issued soon after Alberto Gonzales began his tenure as

73. Yoo Memorandum, supra note 69.

74. Dan Eggen \& Josh White, Memo: Laws Didn't Apply to Interrogators, WASH. Post, Apr. 2,2008 , at A1.

75. Id.

76. Id.

77. Press Release, Am. Civil Liberties Union, Secret Bush Administration Torture Memo Released Today in Response to ACLU Lawsuit (Apr. 1, 2008), available at http://www.aclu.org/ safefree/torture/34747prs20080401.html.

78. Eggen \& White, supra note 74.

79. Id.

80. Posting of Marty Lederman to Balkinization, Full Employment Memo for Bloggers (and Prosecutors?), http://balkin.blogspot.com/2008/04/full-employment-memo-for-bloggers-and.html (Apr. 1, 2008, 20:25 EST).

81. Shane et al., supra note 51. 
Attorney General in February 2005, over the objection of then-Deputy Attorney General James Comey. ${ }^{82}$

Fifth, a late 2005 opinion was drafted after Congress passed the Detainee Treatment Act of $2005,{ }^{83}$ which had specifically outlawed some harsh interrogation techniques. ${ }^{84}$ This opinion confirmed that the CIA practices could be reconciled with the Detainee Treatment Act's restrictions, once again providing legal cover for CIA interrogators, should later decision makers conclude that the practices were illegal. ${ }^{85}$

Finally, an unpublished 2006 executive order-reviewed and approved by the OLC-confirmed authorization for the use of "enhanced" interrogation techniques. ${ }^{86}$ Additional memoranda regarding interrogation techniques have been issued, but not made public. ${ }^{87}$

Much of the substantive criticism of these memos has turned on the expansive assertion of executive power, ${ }^{88}$ the resulting erosion of due process and human rights protections for persons designated as "enemy combatants," ${ }^{\circ 9}$ and the weakening of privacy and civil liberties protections of U.S. citizens. ${ }^{90}$ Procedurally, the Bush administration exploited a structural flaw, leveraging the lack of a requirement to disclose its legal policy to make the OLC a tool for the administration,

82. Id. It was later revealed that certain members of Congress were briefed on the use of waterboarding of prisoners as early as 2002 , but that they were forbidden from taking written notes on the brief, or from disclosing their knowledge to anyone, including their own staff members. Joby Warrick \& Dan Eggen, Hill Briefed on Waterboarding in 2002, WASH. PoST, Dec. 9, 2007, at A1. Rep. Jane Harman noted that she filed a classified letter objecting to the program, but was prevented from speaking publicly due to the rules of secrecy governing her role on an intelligence committee. Id.

83. Pub. L. No. 109-148, 119 Stat. 2739 (2005).

84. The Senate followed up on September 26, 2006, by voting 53-46 not to ban waterboarding as an interrogation technique. Oversight Hearing Transcript, supra note 7, at 4.

85. Shane et al., supra note 51.

86. Id.

87. Id.

88. The assertion of expansive additional powers by a President is not a phenomenon unique to the United States. Jenny S. Martinez, Inherent Executive Power: A Comparative Perspective, 115 YALE L.J. 2480, 2506 (2006); Thomas Poguntke \& Paul Webb, The Presidentialization of Politics in Democratic Societies: A Framework for Analysis, in The Presidentialization of Politics 1,1 (Thomas Poguntke \& Paul Webb eds., 2005).

89. Eggen \& White, supra note 74; Editorial, There Were Orders to Follow, N.Y. TIMES, Apr. 4, 2008, at A22 (noting that the Yoo Memorandum was "81 pages of twisted legal reasoning to justify President Bush's decision to ignore federal law and international treaties and authorize the abuse and torture of prisoners"); see also Yoo Memorandum, supra note 69, at 1 ("[T] he Fifth and Eighth Amendments, as interpreted by the Supreme Court, do not extend to alien enemy combatants held abroad.").

90. See generally Sims, supra note 72 . 
providing legal comfort for controversial actions for government actors and private cooperators. ${ }^{91}$

\section{PRocess CONCERNS AT THE OLC DURING TIMES OF POLITICIZATION}

Critics of the George W. Bush administration argued that the OLC in earlier administrations was able to maintain a culture of nonpoliticization in order to provide the soundest legal advice possible, within some political constraints. ${ }^{92}$ In contrast, the OLC in the Bush administration, particularly after the terrorist attacks of September 11, 2001, arguably gave political goals primacy over the best possible legal advice. ${ }^{93}$

The marked lack of information disclosure from the Bush administration regarding legal policy ${ }^{94}$ served to enable and increase the politicization, as there existed few external checks on the content and quality of the legal opinions, and little public or congressional knowledge of the use and reliance upon these policies. ${ }^{95}$

\section{A. Culture of the OLC Under Previous Administrations}

The OLC, at least in times of peace, historically has maintained its reputation for high-quality legal analysis and executive branch constitutional interpretation due to its long-standing culture of independence from the political motivations of any given administration. ${ }^{96}$ The fact that memoranda drafted during previous

91. GolDSMITH, supra note 8, at 64-68 (noting that then-White House Counsel Alberto R. Gonzales began, in early 2002, looking for ways to provide legal comfort for government actors in light of the restrictions of the Geneva Conventions, War Powers Resolution, FISA and other statutes); Neal Kumar Katyal, Internal Separation of Powers: Checking Today's Most Dangerous Branch from Within, 115 YALE L.J. 2314,2337 (2006) ("[When the high-ranking officials at OLC] become advocates ... the system breaks down. The decisions of that Office begin to look suspect, resembling a courtroom flush with political influence rather than law.").

92. See GOLDSMITH, supra note 8, at 33 ("[T]he office has developed powerful cultural norms about the importance of providing the President with detached, apolitical legal advice, as if OLC were an independent court inside the executive branch.”). See generally Dellinger et al., supra note 10 .

93. GOLDSMITH, supra note 8 , at 33 .

94. Scheppele, supra note 43, at 858-59 (calling the lack of disclosure regarding executive branch legal policy "unprecedented and not in keeping with the general American approach to emergency powers").

95. Eggen \& White, supra note 74 (noting that the top lawyers in the different military branches were not involved in the development of the Yoo Memorandum, nor were they given copies of the Memorandum once it had been prepared and implemented).

96. GOLDSMITH, supra note 8 , at $33,145$. 
administrations, in which the President was of a different political party, were still cited with approval by OLC lawyers in a different administration with different political goals evidences this impartiality. ${ }^{97}$

Even though the career lawyers at the OLC report to political appointees, common OLC practice under most administrations prioritized the quality and impartiality of the legal opinions over their political utility. ${ }^{98}$ To further this goal, the OLC strove to avoid political advocacy whenever possible. ${ }^{99}$ Further, there was an understanding that without the belief that the OLC was setting forth objective legal policy, the credibility of the OLC would be severely jeopardized in the eyes of the public and the other parts of government. ${ }^{100}$

\section{B. Changes in OLC Procedures During the Bush Administration}

OLC cultural norms and processes during the Bush administration changed significantly and were a result of the war-time outlook of the administration and its desire for the maximum possible presidential authority in constitutional decision-making during the war on terror. ${ }^{101}$ First, the administration severely limited information disclosure on many levels: within the Department of Justice, within the administration as a whole, and to other branches of government and the public. ${ }^{102}$ Second,

97. See Posting of Marty Lederman to Balkinization, Understanding the OLC Torture Memos (Part 1), http://balkin.blogspot.com/2005/01/understanding-olc-torture-memos-part-i.html (Jan. 7, 2005, 9:15 EST) ("[I]n issuing its new memo OLC has taken a critically important step toward restoring the office's reputation for providing rigorous and impartial legal advice."); Posting of Michael C. Dorf to Findlaw, The Justice Department's Change of Heart Regarding Torture: A FairMinded and Praiseworthy Analysis That Could Have Gone Still Further, http://writ.news. findlaw.com/dorf/20050105.html (Jan. 5, 2005).

98. Johnsen, supra note 6, at 1577.

99. Shane et al., supra note 51.

100. Moss, supra note 22, at 1311-12.

101. Oversight Hearing Transcript, supra note 7, at $2-3$ ("[Senate oversight] efforts revealed a Department of Justice gone awry.... [Investigation revealed] the United States Attorney firing scandal, a confrontation over the legality of the administration's warrantless wiretapping program, the untoward political influence of the White House at the Department of Justice, and the secret legal memos excusing all manners of excess. And the crisis of leadership has taken a heavy toll on the tradition of independence that's long guided the Justice Department, provided it with safe harbor from political interference.”) (statement of Sen. Patrick Leahy, Chairman, Sen. Judiciary Comm.).

102. See Oversight Hearing Transcript, supra note 7, at 3 (statement of Sen. Patrick Leahy) (noting the practices of the Justice Department are leading it to be a "department of cloaking misguided policies under veiled secrecy, leaving Congress, the courts, but especially the American people in the dark"); Eggen \& White, supra note 74 ("The top lawyers for each military service, who were largely excluded from the group, did not receive a final copy of Yoo's March memo and did not know about the group's final report for more than a year."); Philip Shenon \& Eric Lichtblau, Justice Nomination Seen as Snub to Democrats, N.Y. TIMES, Jan. 24, 2008, at A16 (noting that the nomination of Steven G. Bradbury to head up the OLC had stalled repeatedly as the Department of Justice refused to provide Congress copies of OLC opinions on various terrorism issues). 
the nondisclosure of legal opinions and the opacity of the OLC created an environment in which other changes could be effected without outside oversight, including political influence on content and conclusions of the legal opinions drafted by the OLC. ${ }^{103}$ Third, the lack of information disclosure led to the breakdown of other norms such as appropriate supervision within the $\mathrm{OLC}^{104}$ and the use of external checks, including consultation with the general counsels for relevant administrative departments, in developing legal policy. ${ }^{105}$ Relying on secret legal policy compromised the quality of legal analysis and the credibility of the OLC, and denigrated its ability to give legal comfort that would withstand congressional or public scrutiny.

\section{Lack of Information Disclosure}

One major shift from prior administrations was the degree to which information regarding legal policy was not shared with other members of the Bush administration, or with Congress, despite specific requests for that information. ${ }^{106}$

Many of the controversial OLC opinions related to national security would likely remain unknown to the public but for leaks of the relevant memoranda or other key documents, ${ }^{107}$ or protracted litigation

103. Oversight Hearing Transcript, supra note 7, at 72 ("I'm worried we're not getting enough clarity on critical issues. We have heard reference to legal opinions, to justifications, facts that remain hidden from the Congress, the American people. And it's a hallmark of our democracy that we say what our laws are and what conduct they prohibit. We've seen what's happened when hidden decisions are made in secret memos and that's held from the American people, held from their representatives here in Congress. It erodes our liberties, but it undermines our values as a nation of laws.") (statement of Sen. Patrick Leahy).

104. GOLDSMITH, supra note 8 , at 167 .

105. Eggen \& White, supra note 74.

106. See, e.g., Oversight Hearing Transcript, supra note 7; Order Granting Plaintiffs' Motion for Reconsideration, ACLU v. Dep't of Def., No. 04 Civ. 4151 (S.D.N.Y. May 8, 2008), available at $\mathrm{http} / / / \mathrm{www}$. aclu.org/pdfs/safefree/aclu_v_dod_ordergranting_motionforreconsideration.pdf

[hereinafter ACLU FOIA Order] (granting an FOIA request for OLC opinions on the parameters of harsh interrogation techniques); Shenon \& Lichtblau, supra note 102. Additionally, the most visible examples of stonewalling by the Justice Department do not relate to the OLC opinions themselves. Instead, they involve issues such as the Justice Department's failure to comply with congressional subpoenas for documents related to the potentially politically motivated firings of certain U.S. Attorneys, as well as then-Attorney General Alberto Gonzales refusing to answer questions about the firings. See Oversight Hearing Transcript, supra note 7, at 3-4 (statement of Sen. Patrick Leahy); see also Carrie Johnson, Internal Justice Dept. Report Cites Illegal Hiring Practices, WASH. Post, July 28, 2008, at A1 (reporting on the findings of the Department of Justice Inspector General that hiring decisions at the Department of Justice were improperly politicized). Although such issues tend to grab the attention of the public, to some extent they are easier issues to confront, since both the request for information and the subsequent refusal to disclose that information are made public.

107. See Johnsen, supra note 6, at $1563,1599$. 
demanding disclosure. ${ }^{108}$ Without a leak or voluntary administration disclosure, Congress and the public remained unaware of executive branch legal policy. ${ }^{109}$ A number of OLC memoranda that delineated the Bush administration's view on the legal parameters of the war on terror were only released to the public in January 2009, in the waning days of the Bush administration. ${ }^{110}$ This lack of disclosure by the OLC is consistent with the attitude of the administration as a whole. Whereas under previous administrations, the disclosure of legal opinions and other documents was routine, ${ }^{112}$ the Bush administration took a dramatically

108. See ACLU FOIA Order, supra note 106.

109. See Oversight Hearing Transcript, supra note 7, at 71-72 (statement of Sen. Grassley); Johnsen, supra note 6, at 1563 .

110. See USDOJ:OLC, What's New At OLC, http://www.usdoj.gov/olc/whatsnew.htm (last visited Jan. 28, 2009) (indicating that many OLC opinions related to national security were made public on January 8, 2009 and January 16, 2009). The January 2009 publications included OLC memoranda from as early as 2001 that dealt with the administration's conduct in the war on terror, as well as congressional oversight efforts. See, e.g., Memorandum from Patrick F. Philbin, Deputy Assistant Att'y Gen., to Counsel to the President (Nov. 6, 2001), available at www.usdoj.gov/olc/ 2001/pub-millcommfinal.pdf (made public January 8, 2009).

112. One significant shift in information disclosure is the difference in treatment of requests under the Freedom of Information Act (FOIA) between the Clinton administration and the Bush administration. Compare Memorandum from John Ashcroft, Att'y Gen., to the Heads of all Fed. Dep'ts and Agencies (Oct. 12, 2001), available at http://www.usdoj.gov/oip/011012.htm (stating that "[w] hen you carefully consider FOIA requests and decide to withhold records, in whole or in part, you can be assured that the Department of Justice will defend your decisions unless they lack a sound legal basis"), with Memorandum from Janet Reno, Att'y Gen., to the Heads of Dep'ts and Agencies (Oct. 4, 1993), available at http://www.usdoj.gov/oip/foia_updates/Vol_XIV_3/page3.htm ("The Department [of Justice] will no longer defend an agency's withholding of information merely because there is a 'substantial legal basis' for doing so. Rather, in determining whether or not to defend a nondisclosure decision, we will apply a presumption of disclosure." (citation omitted)). Congress's attempts to strengthen FOIA in December 2007, were undermined by the Bush administration's efforts to have disputes mediated by the Department of Justice, as opposed to the less partisan National Archives. See Editorial, The Cult of Secrecy at the White House, N.Y. TIMES, Feb. 7, 2008, at A30. 
different view. ${ }^{113}$ Reliance on secret laws - near anathema to the rule of law-became routine.

The Bush administration's stance, although subject to considerable criticism, ${ }^{114}$ did not violate rules or codified procedures of the OLC. ${ }^{115}$ The processes for developing and publicizing legal policy within the OLC, within the Department of Justice, or even within the administration as a whole have historically operated according to uncodified and informal customs and cultural norms. ${ }^{116}$

Although those customs and norms were adhered to by many prior administrations, the Bush administration chose to alter the processes by which legal policy is developed and disseminated: ${ }^{117}$ first, in how the OLC opinions are used for political purposes; ${ }^{118}$ second, in whose input was sought in the development of legal policy; ${ }^{119}$ and third, in not sharing the legal opinions with administration actors directly affected by the opinions. ${ }^{120}$

This is particularly evident in certain OLC opinions involving issues of national security and the administration's conduct in the war on terror.

113. See Sudha Setty, The President's Question Time: Power, Information, and the Executive Credibility Gap, 17 CORNELL J.L. \& PUB. POL'Y 247, 256-60 (2008) (discussing the lack of information forthcoming from the Bush administration); Editorial, The President's Lawyers, WASH. Post, Mar. 11, 2008, at A18.

114. See Walter E. Dellinger et al., Guidelines for the President's Legal Advisors, 81 IND. L.J. $1345,1350-51$ (2006) (stating that the OLC should publicly explain any advice contrary to statutory requirements); Lederman, supra note 80 ("The classification of this memo was entirely unjustifiable.”).

115. GolDSMITH, supra note 8 , at 33 (noting that the OLC "is subject to few rules to guide its actions and has little or no oversight or public accountability"); Johnsen, supra note 6, at 1578-79 (discussing the need for the OLC to adhere to internal guidelines). This lack of mandated disclosure of OLC memoranda is properly viewed in the context of the statutory requirement to disclose intelligence programs to congressional intelligence committees. See 50 U.S.C. $\S \S 413,413 a, 413 b$ (Supp. IV 2004) (requiring that the President, Director of National Intelligence, or head of relevant departments keep the congressional intelligence committees "fully and currently informed" of various intelligence activities).

116. Johnsen, supra note 6, at 1578-79. Although this lack of structure has been the norm through numerous administrations since the OLC was founded, the significant shift in culture and the politicization of the OLC under the Bush administration exposed that many of the customary practices and procedures used by OLC lawyers and the Department of Justice in previous administrations were not required by any kind of internal or external control. Therefore, the Bush administration viewed those norms as non-binding and chose not to enforce them. GOLDSMITH, supra note 8 , at $33,79-80$.

117. GolDSMITH, supra note 8 , at 166-67.

118. See id. at 95-98 (discussing the OLC's impact in helping to shape policy).

119. Id. at 116 (noting OLC policy limiting readership of controversial opinions to a small group of lawyers); Johnsen, supra note 6, at 1564.

120. GOLDSMITH, supra note 8, at 166-67 (noting OLC policy excluded the State Department from access to the opinions); Johnsen, supra note 6, at 1600 ("OLC apparently either never solicited or simply ignored the advice of the Department of State and the Criminal Division of the Department of Justice."). 
The Bybee Memorandum and Yoo Memorandum authorization of extremely harsh interrogation techniques is an example of how the process by which legal policy is developed has changed considerably, and how external controls are not used to ensure that the legal opinions being generated reflect the best thinking of individuals familiar with the relevant areas of law. ${ }^{121}$

\section{Political Pressure on the OLC}

Attempts to convince the Bush administration to follow the precedent set by Lincoln and Franklin Roosevelt, which turned on publicizing the administration's desired policy position and lobbying for congressional and public support, were limited and ultimately unsuccessful. ${ }^{122}$

The route of Lincoln and Roosevelt was consistently rejected, and process-oriented secrecy brought additional political pressure to bear on the OLC. This pressure transformed the OLC into an advocate that "'lost its ability to say no" to the White House, ${ }^{123}$ a transformation underscored by those who referred to Yoo as "Dr. Yes" for his acquiescence to any and all White House requests for legal justifications. $^{124}$

Additionally, decisions about hiring, promotion, and resignation in the OLC appeared to turn on perceptions of loyalty to the administration and its preferred legal positions. Career lawyers who tried to remain politically neutral in their legal analyses were ostracized ${ }^{125}$ or passed

121. See GoLDSMITH, supra note 8 , at $167-72$.

122. Id. at $81-85$. Goldsmith recounts that his attempts to restore process controls at the OLC were rejected by David Addington, counsel to Vice President Dick Cheney and an influential voice in shaping executive branch legal policy. Id. at 80-82. In another exchange, Goldsmith recalls offering his opinion to Addington that the Fourth Geneva Convention "applied to all Iraqi civilians, including terrorists and insurgents." Rosen, supra note 52, at 43. Addington was "livid" and replied that the President had made up his mind that the Geneva Conventions did not apply to terrorists, and then told Goldsmith, “"[y]ou cannot question his decision." Id. Goldsmith left his post after nine months, due in part to his unwillingness to provide the administration legal comfort for all of its proposed national security programs. $I d$.

123. Shane et al., supra note 51 (quoting Douglas Kmiec, head of the OLC under Presidents Reagan and George H.W. Bush).

124. Id. (referring to then-Attorney General John Ashcroft's private nickname for John Yoo).

125. James Comey, former Deputy Attorney General, prepared his resignation after then-White House Chief of Staff Andrew Card and then-White House Counsel Alberto Gonzales attempted to have then-Attorney General John Ashcroft sign off on a memo that claimed that an even more aggressive version of the administration's warrantless wiretapping program was legally sound while Ashcroft was hospitalized and Comey was acting Attorney General. Dan Eggen \& Paul Kane, Gonzales Hospital Episode Detailed, WASH. Post, May 16, 2007, at A1. 
over for promotion, ${ }^{126}$ while OLC lawyers perceived to be sympathetic to the White House legal agenda were promoted and supported, ${ }^{127}$ with the implication that White House support would be withdrawn if that loyalty were brought into question. ${ }^{128}$

Political pressure, combined with OLC opinions shrouded in secrecy from inception through issuance, undermined the credibility and quality of legal reasoning found in OLC opinions. ${ }^{129}$ The lack of self-policing by the OLC and the administration was compounded by a lack of significant oversight from supervisors within the Justice Department, ${ }^{130}$ lawyers from other parts of the administration, and Congress.

For example, Jack Goldsmith notes that prior to his tenure as OLC head, even National Security Agency lawyers were denied access to OLC's legal opinions governing National Security Agency activities. ${ }^{131}$ This attitude reflected the administration's view that it had no obligation to share information with any agency within its own administration, even when the legal opinion in question directly related to the activities of that agency.

126. Shane et al., supra note 51 (noting that when Alberto Gonzales sought to fill the vacancy at the OLC after Goldsmith's departure, he "informed Daniel Levin, the acting head who had backed Mr. Goldsmith's dissents and signed the new opinion renouncing torture, that he would not get the job").

127. Id. Steven G. Bradbury, perceived to be sympathetic to the White House's desire for legal justification for its preferred course of action, acted as head of the OLC after Levin was advised he would not be nominated. Bradbury was not, however, immediately nominated to the Senate for confirmation to the post. Instead, he was put through a probationary period by the White House at the suggestion of Harriet Miers, then-White House counsel. Id.

128. Id. (citing Charles J. Cooper, head of the OLC under President Reagan, as viewing the probationary period as problematic from a partiality perspective). Bradbury was later nominated by President Bush, but was never confirmed as head of the OLC, due in part to administration rejection of the Senate request for the release of OLC memoranda authored by Bradbury. See Philip Shenon \& Eric Lichtblau, White House Renews Battle Over Lawyer Who Signed Interrogatories, N.Y. TIMES, Jan. 24, 2008, at A16 ("[The OLC's] nominations stalled in the Senate because of a dispute with the Justice Department over its failure to provide Congress with copies of legal opinions on a variety of terrorism issues.").

129. Margulies, supra note 32, at 3-4.

130. In the case of the Bybee Memorandum, Jay Bybee signed off on John Yoo's draft without making himself an expert in that area of law, or consulting someone who was an expert in national security, war powers, and humanitarian law. GOLDSMITH, supra note 8, at 22-23. Then-Attorney General John Ashcroft did not provide such supervision, and was actually bypassed in the development of the Bybee Memorandum by virtue of Yoo's close relationship with top White House officials. See Rosen, supra note 52, at 43 . Commentators have noted that the lack of impartiality and the overtly political nature of the Bybee Memorandum have compromised its utility and the integrity of the OLC generally. See Dorf, supra note 97 ("[T]he August 2002 memo can only be described as a serious departure from longstanding OLC practice. In content and tone, the memo reads much like a document that an overzealous young associate in a law firm would prepare in response to a partner's request for whatever arguments can be concocted to enable the firm's client to avoid criminal liability.").

131. Rosen, supra note 52, at 45 . 
Further, lawyers within the administration, including general counsels of the military, objected strongly to the substance of the Bybee Memorandum on torture, but their input was not recognized or considered in the drafting and promulgation of the Memorandum. ${ }^{132} \mathrm{~A}$ lack of such external checks established the environment for the OLC to become a "hothouse for rogue ideological opinion, protected from the winds of scrutiny and peer review and other things by the classification shield." "133

This highly insulated environment not only denigrates the quality of legal policy, but brings into question whether some OLC attorneys acted in violation of legal ethical standards. ${ }^{134}$ Given the significant overhaul of processes at the OLC, it is unsurprising that administration critics have called for mandatory disclosure of OLC memoranda. ${ }^{135}$

\section{IS MANDATORY Disclosure REALLY THE SOLUTION?}

Mandatory disclosure of OLC memoranda that articulate executive branch legal policy and provide legal comfort to administration actors will increase the quality and integrity of OLC opinions. Further, the actions of the Bush administration demonstrate that internal practices of voluntary disclosure are not effective in maintaining transparency and

132. See Jane Mayer, The Memo: How an Internal Effort to Ban the Abuse and Torture of Detainees Was Thwarted, NEW YORKER, Feb. 27, 2006, at 32 (discussing the opposition of U.S. Navy General Counsel Alberto Mora to the policy articulated in the Bybee Memorandum); Josh White, Military Lawyers Fought Policy on Interrogations, WASH. POST, July 15, 2005, at A1 (quoting an Armed Service official concerned that "JAG objections may have fallen on deaf ears, and that the policy that emerged may have opened the door to abuses at U.S. detention facilities around the world").

133. Oversight Hearing Transcript, supra note 7, at 68 (statement of Sen. Sheldon Whitehouse).

134. See Clark, supra note 7, at 471 ("John Yoo and Jay Bybee apparently failed to comply with their ethical obligations to provide candid legal advice and to adequately inform their client ....”); Margulies, supra note 43, at 644 ("[T]he charged atmosphere of national security advice and litigation can cast legal ethics as a luxury that the attorneys can ill afford."); see also Jack M. Balkin \& Sanford Levinson, Law and the Humanities: An Uneasy Relationship, 18 YAlE J.L. \& Human. 155,185 (2006) ("Legal academics have debated whether [lawyers in the OLC] were simply doing their professional duty by representing their clients, or, on the contrary, were betraying their professional commitments in the deepest sense."). The question of professional responsibility in the OLC continues to be of concern to many scholars. E.g., Harold Hongju Koh, Dean, Yale Law Sch., Yale Law School Commencement Remarks (May 26, 2008), available at http://www.law.yale.edu/ documents/pdf/News_\&_Events/commencement08KohRemarks.pdf.

135. Dellinger et al., supra note 10, at 1607-08; Neal Katyal, Jack Goldsmith \& Jamie Gorelick, Comments at Conference: A Conversation Regarding the Role of the Justice Department in the War on Terror (Apr. 10, 2008), available at http://www.law.georgetown.edu/webcast/eventDetail.cfm? eventID $=539$, (comments at minutes 28:00-38:00) (noting that although there may be some legal objections to mandatory disclosure of OLC memoranda, it would be a sound policy for future administrations to follow). 
that voluntary practices may not work in future administrations. ${ }^{136}$ Disclosure should thus be mandated by Congress. ${ }^{137}$

\section{A. Greater Information Disclosure Increases the Integrity of OLC Opinions}

One effect of nondisclosure is legal memoranda that reflect underdeveloped legal reasoning, a criticism that has been levied against previously secret OLC memoranda that were either leaked to the public or eventually declassified. ${ }^{138}$ Making disclosure the default standard encourages self-policing by OLC lawyers. Disclosure would also generate political and public sentiment regarding legal policies, the same way that congressional lawmaking and judicial opinions are subject to public scrutiny. ${ }^{139}$ Obviously, public outcry could influence an administration to back away from a controversial policy, as has apparently occurred in the case of the Bybee and Yoo Memoranda; or, as in the cases of Lincoln and Roosevelt, publication of legal policy could serve to garner public and congressional support for controversial policies.

Although some disclosures were made after the inception of the surveillance program to certain members of Congress, ${ }^{140}$ the nature of

136. Some have suggested overhauling the entire structure of the OLC to account for the political pressure on OLC attorneys. See Katyal, supra note 91, at 2337-38 ("OLC should be stripped of its adjudicatory role and permitted to function only as an advisor to the administration.").

137. Such oversight measures are often tied to Congress's spending power, and are included in appropriations measures. E.g., The 21st Century Department of Justice Appropriations Authorization Act, $\S 202$, 28 U.S.C. $\S 530$ (D) (2002). For a discussion of challenges surrounding enforcement of congressionally mandated disclosure see infra Part V.B.

138. See Rosen, supra note 52, at 42 (noting that when he started at the OLC in 2003, Jack Goldsmith reviewed the Bybee and Yoo Memoranda and found them to be "tenditious, overly broad and legally flawed").

139. Courts have long recognized the importance of transparency to ensure the accuracy of administrative decision-making. E.g., Air Transp. Ass'n of Am. v. Dep't of Transp., 900 F.2d 369, 375 (D.C. Cir. 1990), vacated, 498 U.S. 1077 (1991) ("These [notice-and-comment] procedures reflect Congress' 'judgment that ... informed administrative decision making require[s] that agency decisions be made only after affording interested persons' an opportunity to communicate their views to the agency. Equally important, by mandating 'openness, explanation, and participatory democracy' in the rulemaking process, these procedures assure the legitimacy of administrative norms." (citation omitted)); Chocolate Mfrs. Ass'n v. Block, 755 F.2d 1098, 1103 (4th Cir. 1985) ("The purpose of the notice-and-comment procedure is both "to allow the agency to benefit from the experience and input of the parties who file comments ... and to see to it that the agency maintains a flexible and open-minded attitude toward its own rules.' The notice-and-comment procedure encourages public participation in the administrative process and educates the agency, thereby helping to ensure informed agency decisionmaking." (citation omitted)).

140. See Johnsen, supra note 6 , at 1563, 1600-01 (noting that after-the-fact disclosures to Congress do not help maintain best practices in crafting and implementing policy). 
those communications were such that no benefit of accountability accrued. ${ }^{141}$ For example, limited aspects of the warrantless wiretapping program were disclosed to the "Gang of Eight," a bipartisan group of members of Congress. ${ }^{142}$ However, this information was not a complete briefing, and the attendees were under the severe restriction of not being allowed to reveal the information learned in the meetings, including to members of their staffs or other members of the congressional intelligence committees. ${ }^{143}$

If briefing attendees had any objection to the nature of the surveillance program, their only recourse was to complain to those providing the briefing, or discreetly communicate with the administration to voice their objections, with the hope that those objections would be considered. ${ }^{144}$

This disclosure becomes meaningless unless the recipients of the information-here, individuals within Congress-evince the will to disregard the unreasonable secrecy limitations placed on them by the administration, or to leverage their power in Congress to exert strong and meaningful pressure on the administration to change its legal policies. The public debate triggered by the disclosure would increase the likelihood that the administration would produce a more effective, lawful, policy. ${ }^{145}$ For example, because information recipients were not able to exercise meaningful oversight or develop a cogent legislative response to the wiretapping program, ${ }^{146}$ Congress is still looking for ways to negotiate the exposure of classified information while still conducting useful, legitimate oversight of the Department of Justice. ${ }^{147}$

\footnotetext{
141. Kitrosser, supra note 5, at 1058-59.

142. Id. at 1058.

143. Id. at 1058-59; Eric Lichtblau \& David E. Sanger, Administration Cites War Vote in Spying Case, N.Y. TIMES, Dec. 20, 2005, at A1; see also Warrick \& Eggen, supra note 82 (highlighting the restrictions on congressional information recipients in the context of the administration's use of waterboarding during the interrogation of detainees).

144. Dan Eggan, Limiting NSA Spying is Inconsistent With Rationale, Critics Say, WASH. PosT, Feb. 8, 2006, at A5; David E. Sanger, In Address, Bush Says He Ordered Domestic Spying, N.Y. TIMES, Dec. 18, 2005, at A1.

145. See Lederman, supra note 80.

146. Suzanne E. Spaulding, Power Play: Did Bush Roll Past the Legal Stop Signs?, WaSH. Post, Dec. 25, 2005, at B1; Sheryl Gay Stolberg, Senators Left Out of Loop Make Their Pique Known, N.Y. Times, May 19, 2006, at A20.

147. To that end, Congress passed Senate Bill 274, The Federal Employee Protection Act of 2007 , to protect whistleblowers who report abuses in the area of national security to Congress. In January 2008, Attorney General Mukasey and others objected to such protections based on national security concerns. Oversight Hearing Transcript, supra note 7, at 22-23 (statement of Sen. Grassley).
} 
In response to such criticisms, the Bush administration contended that briefings to a limited number of congresspeople, even with the significant restrictions on information flow in place, constituted an adequate check on executive branch legal policy-making. ${ }^{148}$

Mandatory disclosure would also force a higher level of self-policing by the OLC and the administration because of the crucial offensive and defensive functions served by the memoranda. Offensively, the OLC memoranda in question lay out an expansive view of presidential power regarding the legality of certain national security programs.

Defensively, providing legal comfort to protect interrogators and others against future prosecution is one of the primary reasons for the existence of certain OLC memoranda. ${ }^{149}$ CIA agents referred to the immunity provisions of the Bybee Memorandum as the "Golden Shield" that protected them from future liability if the interrogation techniques were ever made public. ${ }^{150}$ Evidence suggests that CIA interrogators would not have conducted any "enhanced interrogations" without specific legal approval, ${ }^{151}$ and that the Bybee and Yoo Memoranda's blanket immunity for those involved in the decision-making on the use of harsh techniques encouraged top White House officials to continue asking the CIA to use those techniques. ${ }^{152}$

Because OLC opinions were essential to convince CIA operatives that they would not face prosecution or legal liability in the future, it is highly unlikely that such harsh techniques would ever have been used without the formal protection of an OLC opinion deeming the actions to be legal. ${ }^{153}$ If such memoranda were, as a default, made public, then the

148. Wartime Executive Power and the National Security Agency's Surveillance Authority: Hearing Before the S. Comm. on the Judiciary, 109th Cong. 30 (2006) [hereinafter Wartime Executive Power], available at http://www.fas.org/irp/congress/2006_hr/nsaserv.pdf (statement of Alberto R. Gonzales, Attorney General of the United States).

149. Mink, supra note 62 ("[Both the Bybee and Yoo Memoranda] provide excuses for interrogators and their military and civilian supervisors. These amount to variations of 'I was just following orders,' self-defense (of the nation) or necessity (to prevent a greater evil).").

150. Jan Crawford Greenburg et al., Sources: Top Bush Advisors Approved 'Enhanced Interrogation,' ABCNEWS, Apr. 9, 2008, http://abcnews.go.com/TheLaw/LawPolitics/story?id=458 3256; Editorial, There Were Orders to Follow, N.Y. TimeS, Apr. 4, 2008, at A22 (noting that the Yoo Memorandum offered a "detailed blueprint for escaping accountability").

151. See Greenburg et al., supra note 150 (noting efforts to avoid the CIA being painted as a "rogue agency").

152. Lara Jakes Jordan \& Pamela Hess, Associated Press, Cheney, Others OK'd Harsh Interrogations, ABCNEWs, Apr. 11, 2008, available at http://abcnews.go.com/politics/wirestory? id $=4631535$. Goldsmith describes the defensive role of OLC memoranda as " free get-out-of-jail cards" " being dispensed to the interrogators, and an "“advance pardon"” for controversial actions. See Rosen, supra note 52, at 43.

153. See Scott Shane, Nominee's Stand May Avoid Tangle of Torture Cases, N.Y. TIMES, Nov. 1,2007 , at A20 ("“A]ny statement by Mr. Mukasey that waterboarding is torture could fuel criminal 
internal pressure to offer the best possible assessment of whether the use of harsh techniques is legal would increase dramatically.

\section{B. Nature of the Mandatory Disclosure}

A new disclosure requirement should apply to almost all OLC opinions and result in a timely disclosure to the public whenever possible. ${ }^{154}$ Exceptions should be made for limited purposes, including when a particular administrative agency requests confidentiality and does not actually rely on the advice given in a particular opinion. ${ }^{155}$

Such a system would bring the OLC's disclosure practices into line with the exceptions to disclosure under the Freedom of Information Act ${ }^{156}$ particularly Exemption No. $5,{ }^{157}$ which protects the intra-agency deliberative process. ${ }^{158}$

Mandatory disclosure - at least to Congress, if not to the public - for every OLC opinion that affirms the legality of policies which are then actually implemented by an administration would create a context in which legal comfort is available only from those opinions that are made public. ${ }^{159}$ This flexible standard would allow for retention of confidentiality when necessary and when the opinion sought does not shape actual policy, and would minimize the chilling effect on those seeking legal advice within an administration. ${ }^{160}$ Courts have made clear

charges or lawsuits against those responsible for waterboarding.")

154. Some OLC opinions involving classified information or particularly sensitive national security matters should not be disclosed to the public, but should be made available to Congress under the rubric set forth in the National Security Act of 1947. See infra note 197.

155. Compare Dellinger et al., supra note 10, at 4 ("OLC should consider the views regarding disclosure of the client agency that requested the advice. Ordinarily, OLC should honor a requestor's desire to keep confidential any OLC advice that the proposed executive action would be unlawful, where the requestor then does not take the action." (emphasis added)).

156. Freedom of Information Act, 5 U.S.C. § 552(a)(3), (b)(1)-(9) (2006).

157. $\S 552(\mathrm{~b})(5)$.

158. See, e.g., Nat'l Council of La Raza v. Dep't of Justice, 411 F.3d 350, 356 (2d Cir. 2005) (explaining that the deliberative process privilege "is designed to promote the quality of agency decisions by preserving and encouraging candid discussion between officials"); Tigue v. U.S. Dep't of Justice, 312 F.3d 70, 76 (2d Cir. 2002) (noting that the deliberative process privilege is "a subspecies of work-product privilege that 'covers documents reflecting advisory opinions, recommendations and deliberations comprising part of a process by which governmental decisions and policies are formulated"' (citing Dep't of Interior v. Klamath Water Users Protective Ass'n, 532 U.S. 1, 2 (2001))); Bronx Defenders v. U.S. Dep't of Homeland Security, No. 04-CV-8576-HB, 2005 WL 3462725, at*2 (S.D.N.Y. Dec. 19, 2005) (same).

159. See NLRB v. Sears, Roebuck \& Co., 421 U.S. 132, 161 (1975) (holding that the deliberative process privilege ends when an originally deliberative document is adopted or incorporated by reference into a final agency policy or decision); see also Bronx Defenders, 2005 WL 3462725 , at $* 2$ (same).

160. As the Supreme Court reasoned: 
that the administration should not be permitted "to develop a body of 'secret law,' used by it . . . but hidden behind a veil of privilege because it is not designated as 'formal,' 'binding,' or 'final.'

\section{Potential Impact of New OLC Culture on Future Administrations}

In times of both war and peace, the OLC's cultural norm under previous administrations allowed for some information disclosure and more internal and external controls; critics agree that this previous norm is preferable to the lack of process controls and standard practices during the Bush administration. ${ }^{162}$

However, it is problematic to assume that internal constraints can be successfully re-established to maintain impartiality and best practices ${ }^{163}$ in the OLC if the interaction between the President and Congress remains highly politicized, as during the Bush administration. ${ }^{164}$ This is particularly true if both houses of Congress and the President belong to the same political party - if Congress does not have the political will to exercise at least some oversight of the OLC, mandatory disclosure can and will serve as a backstop. ${ }^{165}$ Further, politicization and political

$[\mathrm{T}]$ he probability that an agency employee will be inhibited from freely advising a decisionmaker for fear that his advice if adopted, will become public is slight. First, when adopted, the reasoning becomes that of the agency and becomes its responsibility to defend .... Moreover, the public interest in knowing the reasons for a policy actually adopted by an agency supports [disclosure].

NLRB, 421 U.S. at 161.

161. Coastal States Gas Corp. v. Dep't of Energy, 617 F.2d 854, 867 (D.C. Cir. 1980).

162. See Johnsen, supra note 6 , at 1564 (encouraging a return to old OLC norms and the use of internal executive branch constraints to maintain those old norms); see also Dellinger et al., supra note 10 .

163. Johnsen, supra note 6, at 1579 (noting that "the power of unwritten tradition alone plainly is inadequate" to maintain OLC best practices).

164. In rare instances, a minority party in Congress has exerted enough political pressure on majority leaders to heighten or maintain oversight. One such example is the Senate Intelligence Committee's completion of its investigation into the flawed intelligence that was reported in the National Intelligence Estimate of 2002. See Patricia Wald \& Neil Kinkopf, Putting Separation of Powers into Practice: Reflections on Senator Schumer's Essay, 1 HARV. L. \& POL'y REV. 41,49 (2007) (noting that political parties are more ideologically polarized than in previous eras). The completion of the Intelligence Committee's work only occurred after Senate Democrats threatened to stall business on the Senate floor. See id. at 48.

165. See George C. Edwards III \& Andrew Barrett, Presidential Agenda Setting in Congress, in POLARIZED POLITICS 109, 133 (Jon R. Bond \& Richard Fleischer eds., 2000) ("[U]nder unified government, ... the majorities in Congress are most likely to defer to the White House's lead."); Setty, supra note 113, at 260 (observing that congressional investigative function is limited in times of one-party government); Mark Tushnet, Controlling Executive Power in the War on Terrorism, 118 HARV. L. REV. 2673, 2679 (2005) (noting that under unified government, Congress tends to support the President without questioning the wisdom of his policies). 
pressure ${ }^{166}$ may be inevitable in times of war. ${ }^{167}$ Politicization that leads to self-interested actions, such as keeping secret potentially controversial legal policies, highlights the need for institutionalized checks and balances such as mandated disclosure. ${ }^{168}$

Finally, asking OLC lawyers to revert to a particular model of best practices is futile if those lawyers already believe that they are adhering to best practices in terms of their legal analysis. ${ }^{169}$ John Yoo, Jay Bybee, and former Attorney General Mukasey made clear that they believed that the legal opinions drafted by the OLC were done so in good faith and through the best possible interpretation of the law. ${ }^{170}$ Goldsmith, a strong critic of some tactics of the administration, stated that everyone he

166. Oversight Hearing Transcript, at 49-50 (statement of Sen. Charles Schumer) (noting some changes in Department of Justice process after Michael Mukasey became Attorney General, including the limitation of contact between White House and Justice Department employees, and other efforts to lessen political influence in Justice Department decision-making).

167. The examples of Lincoln and Roosevelt illustrate this point. See also Scheppele, supra note 43, at 837 ('The 'great presidents,' Lincoln and Roosevelt, played fast and loose with constitutional rules in the name of civil war and economic emergency.").

168. See ThE FederAlist No. 51 (James Madison) ("Ambition must be made to counteract ambition.... It may be a reflection on human nature, that such devices should be necessary to control the abuses of government."); Daryl J. Levinson \& Richard H. Pildes, Separation of Parties, Not Powers, 119 HARV. L. REV. 2312, 2313-14 (2006) ("Madison's account of rivalrous, selfinterested branches is embraced as an accurate depiction of political reality and a firm foundation for the constitutional law of separation of powers."); Setty, supra note 113, at 251-52 ("Under the model of divided government advanced by James Madison, 'ambition would counteract ambition,' keeping the Executive, Legislative, and Judiciary exercising their proper functions - no more and no less.").

169. John Yoo, who drafted at least part of the Bybee Memorandum, maintains that his advice was not politically motivated, and that it represented an impartial, accurate reading of the law:

$[\mathrm{I}] \mathrm{t}$ 's very important not to put in an opinion interpreting a law on what you think the right thing to do is, because I think you don't want to bias the legal advice with these other considerations. Otherwise, I think people will question the validity of the legal advice. They'll say, "Well, the reason they reached that result is that they had certain moral views or certain policy goals they wanted to achieve." And actually I think at the Justice Department and [the OLC], there's a long tradition of keeping the law and policy separate.

Frontline: The Torture Question (PBS television broadcast July 19, 2005) (edited transcript), available at http://www.pbs.org/wgbh/pages/frontline/torture/interviews/yoo.html.

170. From the Department of Justice to Guantanamo Bay: Administration Lawyers and Administration Interrogation Rules, Part III: Before the Subcomm. on the Constitution, Civil Rights, and Civil Liberties of the H. Comm. on the Judiciary, 110th Cong. 2 (2008) [hereinafter Interrogation Rules] (testimony of John Yoo, Professor of Law, University of California Berkeley School of Law), available at http://judiciary.house.gov/hearings/pdfs/Yoo080626.pdf ("[W]e in OLC were determined ... to interpret the law, in good faith ... by operating within the bounds drawn by the laws and the Constitution of the United States. Now as then, I believe we achieved this goal."); Oversight Hearing Transcript, supra note 7, at 9 (remarks of Michael Mukasey, Att'y Gen. of the United States). 
dealt with in the administration "thought they were doing the right thing" "in developing OLC legal opinions. ${ }^{171}$

A different set of principles and practices in the Obama administration OLC seems likely given the vigorous support of transparency by the incoming administration. ${ }^{172}$ However, without further external measures to ensure greater information disclosure, the breakdown of OLC norms during the Bush administration ${ }^{173}$ could recur in any future administration. ${ }^{174}$

The question that remains after all of the hand-wringing over the politicization of the OLC is whether President Obama and every future president will re-establish and abide by those OLC norms, in which case the information disclosure problems highlighted here may not need to be addressed further. However, President Obama or future presidents may find it helpful and self-serving to use the George W. Bush administration as precedent to cement the aggregation of executive power ${ }^{175}$ and limit access to OLC legal policy, ${ }^{176}$ in which case we must consider whether additional structural or institutional measures will be helpful to improve the quality of OLC opinions while maintaining the integrity of sensitive national security programs to which some legal opinions relate. ${ }^{177}$ As one administration critic has put it, "[w] hat was once shocking and

171. Rosen, supra note 52, at 42 .

172. Sheryl Gay Stolberg, On First Day, Obama Quickly Sets a New Tone, N.Y. TIMES, Jan. 22, 2009, at A1 (noting how Obama changed rules on information disclosure on his first full day in office); Eric Lichtblau, Obama Fills Top Justice Department Spots, N. Y. TIMES.COM, Jan. 5, 2009, http://thecaucus.blogs.nytimes.com/2009/01/05/obama-fills-top-justice-department-spots/?scp=1\&sq $=1 / 5 / 09 \% 20$ johnsen\&st $=$ cse (noting that new OLC head, Dawn Johnsen, was a frequent critic of the Bush administration OLC practices)

173. Notably, former Attorney General Mukasey has pointed out that no one at the OLC ever thought that they were promulgating a bad opinion or that they were breaking the law. Oversight Hearing Transcript, supra note 7, at 82.

174. New OLC head, Dawn Johnsen, has acknowledged the need for external checks to maintain the long-term integrity of the OLC. See Dawn E. Johnsen, What's a President to Do? Interpreting the Constitution in the Wake of Bush Administration Abuses, 88 B.U. L. REV. 395, 396 (2008) (encouraging Congress to impose external checks on executive branch constitutional interpretation).

175. See Bruce Ackerman, Terrorism and the Constitutional Order, 75 FordHAM L. REV. 475, 478 (2006) ("[W]hatever new powers are conceded to the President in this metaphorical war [on terror] will be his forever.").

176. Adam Cohen, Op.-Ed., Honey, They Shrunk the Congress, N.Y. Times, Oct. 30, 2007, at A24 ("The issue of reining in presidential power is beginning to gain traction among conservatives ... as they contemplate the possibility of a Democrat ... a president.").

177. See, e.g., Kitrosser, supra note 5, at 1050 ("In matters of congressional oversight generally, it is difficult and important to balance the respective values of information flow to the public, information flow between Congress and the President, and presidential discretion to act swiftly and secretly."). 
unacceptable in America has now been internalized as the new normal." $" 178$

\section{Compensating for a Lack of Checks and Balances}

The lack of effective oversight by the courts and Congress enabled the Bush administration's unwillingness to disclose OLC opinions. ${ }^{179}$ This issue is significantly more problematic in times of unified government - that is, when Congress is aligned politically with the President, as it was from 2000 to 2006 , and as it is now. ${ }^{180}$ However, lack of oversight often persists even in divided government during wartime, when Congress often acquiesces to executive requests with little opposition. ${ }^{181}$ As such, additional institutionalized safeguards, such as mandatory disclosure of opinions, are necessary to offset a lack of effective oversight. ${ }^{182}$

Congressional leaders have admitted the failure of Congress to extract meaningful concessions from the administration in terms of disclosing legal policy or responding to congressional requests for

178. Frank Rich, Op.-Ed., The Coup at Home, N.Y. TIMES, Nov. 11, 2007; see Sanford Levinson, Constitutional Norms in a State of Permanent Emergency, 40 GA. L. REV. 699, 705 (2006); Scheppele, supra note 43, at 839.

179. Editorial, Secrets and Rights, N.Y. TIMES, Feb. 2, 2008, at A18 (citing refusal of the courts to question seriously any administration claim of state secrets).

180. Levinson \& Pildes, supra note 168, at 2371 (citing Joel D. ABERBACH, KeEPING A WATChful Eye: The Politics OF CONGRessional Oversight, 59-75 (1990) (concluding that congressional committees exercised over twenty-six percent more oversight in times of divided government than unified government between 1961 and 1977)). Levinson and Pildes used a simple majority to assess whether a party was able to exert control in the legislature. Id. at 2368-71; see also Setty, supra note 113, at 260-62 (addressing the limits of Congress's investigative function).

181. Barron \& Lederman, supra note 32, at 999-1000; Katyal, supra note 91, at 2321-22 (“A Congress that conducts little oversight provides a veneer of legitimacy to an adventurist President. The President can appeal to the historic sense of checks and balances, even if those checks are entirely compromised by modern political dynamics. With this system in place, it is no surprise that recent calls for legislative revitalization have failed.").

182. When the President looks to leverage his position to gain more power, the legislature is obliged to exercise oversight to control executive overreaching. See AKHIL REED AMAR, AMERICA'S CONSTITUTION: A BIOGRAPHY 111 (2005) (noting that although Congress's oversight function is not specifically enumerated in Article I of the Constitution, it most definitely was an expectation of the framers of the Constitution that Congress would exercise oversight of the executive branch, based on the traditional powers exercised by the English parliaments and the colonial legislatures). See generally Michel Rosenfeld, The Rule of Law and the Legitimacy of Constitutional Democracy, 74 S. CAL. L. REV. 1307 (2001) ("In its broadest terms, the rule of law requires that the state only subject the citizenry to publicly promulgated laws, that the state's legislative function be separate from the adjudicative function, and that no one within the polity be above the law."). 
witnesses and documents that would shed light on administration activities. $^{183}$

\section{HOW VALID ARE ADMINISTRATION JUSTIFICATIONS FOR NONDISCLOSURE?}

National security interests demand a heightened awareness of how sensitive information is treated, since the President has legitimate needs to act quickly and discreetly in times of war. Equally legitimate is the need for the public and Congress to understand the country's legal policy vis-à-vis national security matters. ${ }^{184}$

The administration justifies its nondisclosure of legal policy in two ways: first, through pragmatic arguments, namely that national security concerns demand that the administration strictly limit access to legal policies and interpretations by the executive branch. Second, the administration uses the unitary executive theory to claim that the President can determine unilaterally how the executive branch conducts war. ${ }^{185}$ Both of these arguments are not compelling reasons to forego mandated disclosure.

\section{A. Pragmatic Arguments Justifying Non-Disclosure}

Attempts by Congress during the Bush administration to garner information regarding national security issues met with mixed results, ${ }^{186}$ depending on the political pressure brought to bear on the Bush administration and whether underlying documents or information had already been leaked to Congress. ${ }^{187}$

The Bush administration consistently insisted that nondisclosure of legal policy was necessary to maintain the integrity of U.S. national

183. Oversight Hearing Transcript, supra note 7, at 59-62 (statement of Sen. Charles Schumer).

184. Kitrosser, supra note 5, at 1050.

185. See JaCK N. Rakove, Original MEAnings 356 (1996) (noting that the current debate over the scope of the executive power during wartime can be traced back to discussions between Alexander Hamilton and James Madison over President George Washington's proclamation of neutrality in 1793).

186. See, e.g., Bob Egelko, Mukasey Asked to Explain Terror Call Remarks, S.F. ChroniCle, Apr. 11, 2008 (reporting that the Department of Justice refused a congressional request for elaboration on the necessity of maintaining a warrantless surveillance program).

187. Attempts by Congress to get information related to intelligence gathering, which are mandated under the National Security Act of 1947, should be distinguished from covert operations for the purpose of effecting a military strike against a foreign power, which the President is not under obligation to disclose to Congress. See 50 U.S.C. § 413(b)(e)(1) (2000). 
security interests. ${ }^{188}$ The administration often offered the defense that additional information as to the content of OLC opinions would empower terrorists planning to attack the United States. ${ }^{189}$ Former Attorney General Alberto Gonzales testified that "widespread briefings would pose an unacceptable risk to the national security." 190

To that end, the Bush administration deviated from the prescribed procedure for disclosure of sensitive information to Congress laid out in the National Security Act of $1947 .{ }^{191}$ Whereas the Act mandates briefings to an eight-person subset of congressional intelligence committees for particularly sensitive issues, the Bush administration limited briefings to four people - the top Republican and Democratic members of the two committees. ${ }^{192}$ The reason offered for this deviation was based on national security concerns - namely that the interrogation program should stay secret for fear that al-Qaeda operatives might find out what to expect if captured by the United States. ${ }^{193}$

Former Attorney General Mukasey used the fact that national security is the Justice Department's top priority to support extensive nondisclosure. For example, when considering the complicity of telecommunications companies in the Bush administration's warrantless wiretapping programs, Mukasey refused a Senate request to discuss the actual role of the companies, testifying in a January 2008 hearing that it could compromise national security interests to publicize the "means and methods" used by the administration. ${ }^{194}$

188. See Wartime Executive Power, supra note 148, at 264-320; Johnsen, supra note 6, at 1565.

189. Carol D. Leonnig \& Eric Rich, U.S. Seeks Silence on CIA Prisons, WASH. Post, Nov. 4, 2006, at A1; see Wartime Executive Power, supra note 148, at 107 (suggesting such revelations remind the enemy that they are being monitored); Kitrosser, supra note 5, at 1056 ("[T]he administration has offered no explanation of the purported dangers of revealing the program's very existence beyond the vague assertion that, while terrorists surely already know that the United States can survey their conversations, knowing about the program would remind them of this fact and might lead them to infer that surveillance is broader than they had assumed."); see also Ackerman, supra note 175, at 478-79 (arguing that the rhetoric surrounding the war on terror encourages a public and congressional overreaction of ceding powers to the President).

190. Wartime Executive Power, supra note 148, at 137. See id. passim for further pragmatic arguments in favor of non-disclosure of national security-related legal policy to Congress.

191. 50 U.S.C. $\$ 401(2000)$.

192. Warrick \& Eggen, supra note 82.

193. Id. Critics have offered a second, perhaps more important reason for the desire for secrecy: to avoid public and international censure over the use of the harsh interrogation techniques. When the interrogation program became known more widely in late 2005, the uproar from Congress and the public apparently prompted the administration to modify its program. Id.

194. See Oversight Hearing Transcript, supra note 7, at 6-7, 15-17. Sen. Orrin Hatch agrees with Mukasey's assessment, saying that "the reason for classification is to protect the information from getting in the hands of the wrong people." Id. at 47 (statement of Sen. Orrin G. Hatch). 
Mukasey also refused to disclose whether and under what possible circumstances waterboarding could be used lawfully by U.S. interrogators, because of his fear that such disclosure would embolden terrorists by letting them know what to expect while imprisoned by the United States. ${ }^{195}$

The Bush administration supported this pragmatic argument with the theory that the President is authorized, without disclosure of the program to Congress or the public, by the Authorization to Use Military Force (AUMF) to

use all necessary and appropriate force against those nations, organizations, or persons he determines planned, authorized, committed, or aided the terrorist attacks that occurred on September 11, 2001, or harbored such organizations or persons, in order to prevent any future acts of international terrorism against the United States by such nations, organizations or persons. ${ }^{196}$

The administration has argued that whatever obligation it had to share information with Congress relating to the development of legal policy, whether under previous Justice Department norms or the information-sharing rubric of the National Security Act of $1974,{ }^{197}$ was obviated by the passage of the AUMF. ${ }^{198}$ The view that the AUMF provides a blanket justification for whatever action the administration deems necessary as part of the war on terror was squarely rejected by the Supreme Court in Hamdi v. Rumsfeld. ${ }^{199}$

Despite the reclassification and release in April 2008 of the Yoo Memorandum, numerous OLC opinions remained secret for many years, supposedly for reasons of national security - the same reason offered for the initial nondisclosure of the Yoo Memorandum, which was eventually declassified in response to a FOIA request.

195. Id. at 20-21.

196. Pub. L. No. 107-40 § 2(a), 115 Stat. 224 (2001) (emphasis added). The AUMF was passed by Congress one week after the terrorist attacks of September 11, 2001.

197. See 50 U.S.C. $\$ \S 413(a), 413 a(a)(1)$, (b) (2000).

198. See Pub. L. No. 107-40, § 2(a); Wartime Executive Power, supra note 148, at 264-320; President George W. Bush, President's Radio Address (Dec. 17, 2005), http://www.whitehouse.gov/ news/releases/2005/12/20051217.html;

199. 542 U.S. 507, 533 (2004). 


\section{General Critiques of the Pragmatic Justification}

The claim that disclosure of legal policies is unnecessary and unwise because it would jeopardize U.S. national security interests is questionable, given both the experiences of the United States and other nations, as well as serious concerns about the maintenance of the rule of law.

First, the Bush administration offered no credible evidence that disclosure would harm U.S. national security interests; in fact, it has offered no evidence that the disclosure of the OLC memoranda that were initially withheld from public scrutiny - such as the Bybee and Yoo Memoranda - have negatively impacted U.S. national security programs, other than the resulting bad publicity and embarrassment for the administration. Repeated claims of a need for secrecy based on national security concerns followed by the eventual disclosure of those very OLC opinions ultimately undermined the Bush administration's claim, with more evidence pointing to secrecy being maintained primarily for partisan purposes or because of an unmitigated belief in the unitary executive theory. ${ }^{200}$

Further, the Bush administration failed to make its case as to why legal policies governing the war on terror must be afforded more secrecy than domestic criminal laws and procedural rules. ${ }^{201}$ If the United States or any democratic nation chooses to rely on secret laws and thus deviate so substantially from the general edicts of the rule of law, the public deserves a credible and clear explanation as to why that deviation is necessary.

2. Critiques from a Comparative Perspective: Greater Transparency of Legal Policy Is the Norm

Other countries that face serious national security issues have no mechanism or allowance for secret legal policies to govern national security matters; instead, several nations publicize, disseminate, and publicly debate the same type of legal policy that is being withheld from

200. Editorial, Politics, Pure and Cynical, N.Y. TIMES, Mar. 14, 2007, at A22.

201. Senators involved in administration oversight have noted that domestic criminals are entitled to understand criminal laws and their related punishments; this serves to uphold the rule of law and does not appear to undermine the integrity of the criminal justice system. The administration, however, views the context of national security as fundamentally different than the domestic criminal context and, therefore, not prone to the same conclusions or restrictions as domestic criminal law. Oversight Hearing Transcript, supra note 7, at 42-45 (colloquy between Sen. Russell Feingold and Attorney General Michael Mukasey). 
public scrutiny by the OLC. ${ }^{202}$ A comparative perspective, even of nations with significantly different governmental structures, ${ }^{203}$ provides some context to evaluate the Bush administration's pragmatic justification for non-disclosure.

a. India

India has been coping with serious national security concerns, both internal and external, for the last sixty years. ${ }^{204}$ By some accounts, India has faced a higher number of terrorist acts in recent years than any other nation. $^{205}$

The similarities to the U.S. national security landscape are noteworthy. The central government of India has the responsibility to develop laws and policies to preserve the national security of India, ${ }^{206}$ and the country goes through periods of conflict in which its otherwise supposedly impartial and unbiased legal policy becomes politicized and prone to government overreaching in the areas of civil rights and civil liberties. ${ }^{207}$

202. Kim Lane Scheppele, We Are All Post-9/11 Now, 75 Fordham L. ReV. 607, 609 (2006) (citing Bruce Ackerman, Before the NeXt AtTaCK: Preserving Civil Liberties in AN Age of TERRORISM (2006)) (noting the value of considering other countries' experiences with balancing national security with other constitutional interests).

203. Even countries with similar structural arrangements to the United States have different balances of power with regard to the authorization of wartime actions. For example, Article 29 of the Mexican Constitution requires congressional approval for emergency measures if Congress is in session at the time. If Congress is not in session, it must be convened as soon as possible to make a decision on emergency measures. See Constitución Política de los Estados Unidos Mexicanos [Const.], as amended, art. 29, Diario Oficial de la Federación [D.O.], 5 de Febrero de 1917 (Mex.). This grant of congressional oversight into questions of the legality of proposed measures is particularly striking considering the historic strength of the Mexican presidency. See Jeffrey Weldon, Political Sources of Presidencialismo in Mexico, in Presidentialism AND Democracy IN LATIN AMERICA 225 (Scott Mainwaring \& Matthew Sobert Shugart eds., 1997). Although the Mexican Constitution of 1917 is structured similarly to the U.S. Constitution, Mexican politics has shaped the federal government into one that, until the mid-1990s, was a one-party system in which the President could set his own agenda, likely to be rubber-stamped by the Congress and the courts. Martinez, supra note 88, at 2508; see also Kenneth F. Johnson, Mexico's Authoritarian Presidency, in Presidential Power in Latin American Politics 33, 49 (Thomas V. DiBacco ed., 1977) (discussing "near-absolute decision-making power that has accrued to the president").

204. See Anil Kalhan et al., Colonial Continuities: Human Rights, Terrorism, and Security Laws in India, 20 COLUM. J. OF ASIAN L. 93, 99 (2006).

205. E.g., Arun Venugopal, India Worst Hit by Terrorism in 2004, INDIA ABROAD, Aug. 19, 2005, at A14.

206. INDIA CONST. art. 246, § I, cl. 1-2A; id. art. 246, § III, cl. 1-2.

207. For example, the Defence of India Act of 1962 authorized the central and state governments to broaden their use of preventative detention beyond ordinary laws as a means to quell potential uprisings against the government in response to hostilities in the Jammu and Kashmir region. See Kalhan et al., supra note 204, at 132-33 (citing VENKAT IYER, STATES OF EMERGENCY: THE INDIAN EXPERIENCE 109 (2000)). 
India passed a number of strong antiterrorism laws in recent years which grant additional authority and power to the central government to maintain national security. In the wake of the September 11, 2001 terrorist attacks and attacks on Indian government buildings soon afterward ${ }^{208}$ the Indian Parliament enacted the Prevention of Terrorism Act, 2002 (POTA). ${ }^{209}$ Under POTA, the government, in conducting antiterrorist activities and in case of a self-determined emergency, was authorized to set aside ordinary legal protections with regard to wiretapping any person within India without authorization, ${ }^{210}$ extend the duration and scope of preventative detention measures, ${ }^{211}$ and deny arrested suspects access to counsel during the interrogation period. ${ }^{212}$ Some antiterrorist activities legally authorized under POTA parallel what was initially authorized under the USA PATRIOT Act ${ }^{213}$ — particularly in terms of allowing for enhanced surveillance of U.S. citizens ${ }^{214}$ and increasing authority for other intelligence-gathering efforts. ${ }^{215}$

However, major structural differences exist as to how a parliamentary nation such as India handles the creation of legal policy related to national security measures: one primary difference is that the responsibility for the creation of legal policy is diffuse, with the parliament having the ultimate ability to set the law, while the prime minister and administrative departments play a central, but not decisive, role.

For example, an early iteration of some of the POTA policies was a 2000 report $^{216}$ drafted by the Indian Law Commission, ${ }^{217}$ a nonpartisan

208. The Indian parliament building in New Delhi was attacked in December 2001, with twelve people killed and twenty-two injured in an exchange of gunfire. On This Day: Suicide Attack on Indian Parliament, BBC News OnLINE, Dec. 13, 2001, http://news.bbc.co.uk/onthisday/hi/dates/ stories/december/13/newsid 3695000/3695057.stm.

209. The Prevention of Terrorism Act, No. 15 of 2002, available at http://indiacode.nic.in. Enacted March 28, 2002, this Act replaced the Prevention of Terrorism Ordinance of 2001. Prevention of Terrorism Ordinance, 2001, No. 9 of 2001, available at http://satp.org/satporgtp/ countries/india/document/actandordinances/POTO.htm.

210. The Prevention of Terrorism Act, No. 15 of 2002, supra note 209, § 43. The admissibility of evidence garnered in this manner is established in $\S 45$.

211. Id. § 49 .

212. Id. $\$ 52$.

213. Uniting and Strengthening America by Providing Appropriate Tools Required to Intercept and Obstruct Terrorism Act of 2001, Pub. L. No. 107-56, 115 Stat. 272 [hereinafter PATRIOT Act] (codified in scattered sections of U.S.C.).

214. See id. $\S 218$ (amending the Foreign Intelligence Surveillance Act of 1978 such that electronic surveillance and physical searches need only be justified in "significant" part by the goal of obtaining foreign intelligence).

215. Id. $\S 901$.

216. See LAw COMmission of India, 173Rd RePOrt on Prevention of Terrorism BiLl, Annxure II $\S \S 30,33$ (2000), available at http://lawcommissionofindia.nic.in/tada.htm (containing 
commission of respected lawyers and jurists who respond to government requests for legal recommendations. The 2000 report contained recommendations that the parliament strengthen the central government's power to conduct antiterrorism operations, primarily in light of ongoing domestic unrest that could provoke a national crisis. ${ }^{218}$ The Law Commission, in accordance with its own policies, circulated the report to the public for review and comments. ${ }^{219}$

After the September 11, 2001 terrorist attacks, the Indian parliament began debate on whether to pass the Law Commission's recommendations from the 2000 report into law. ${ }^{220}$ In the meantime, because of the perceived immediacy of the need for the intelligencegathering tools outlined in the Law Commission's report, the executive branch issued the Prevention of Terrorism Ordinance of 2001, a temporary ordinance which put into place the recommended tools. ${ }^{221}$ POTA was enacted in March 2002, containing the same provisions that were in the temporary ordinance. ${ }^{22}$

POTA was met with a great deal of opposition from human rights advocates and opposing political parties, even prior to its enactment. ${ }^{223}$ In response, the Home Minister of India claimed that opponents to the measure were assisting the terrorists, ${ }^{224}$ rhetoric that mirrors the public

provisions similar to those found in POTA regarding the extension at preventative detention and arrested suspects' entitlement to legal counsel).

217. The Law Commission is a non-partisan group of lawyers and judges commissioned by the central government to offer advice and proposals for legal reform. See Law Commission of India, http://www.lawcommissionofindia.nic.in/welcome.html (follow "How Does the Commission Function?" hyperlink) (last visited Oct. 7, 2008).

218. See LAW COMMISSION OF INDIA, supra note $216 \mathrm{ch}$. II (describing unrest in Jammu \& Kashmir, Punjab, Assam, and other regions of India).

219. See Law Commission of India, supra note 217 ("[Proposed reforms are] sent out for circulation in the public and concerned interest groups with a view to eliciting reactions and suggestions. Usually a carefully prepared questionnaire is also sent with the document. The Law Commission has been anxious to ensure that the widest section of people [is] consulted in formulating proposals for law reforms. In this process, partnerships are established with professional bodies and academic institutions. Seminars and workshops are organised in different parts of the country to elicit critical opinion on proposed strategies for reform.").

220. See C. Raj Kumar, Human Rights Implications of National Security Laws in India: Combating Terrorism While Preserving Civil Liberties, 33 DENV. J. INT'L L. \& POL'Y 195, 195-96 (2005) ("The September 11, 2001 attacks in New York and Washington D.C., and the December 13, 2001 attack on the Indian Parliament have intensified the debate regarding the necessity of formulating national security laws in India ....").

221. The Prevention of Terrorism Ordinance, No. 9 of 2001, supra note 209. Under the Indian Constitution, the executive branch has the power to issue ordinances for a short duration to meet unforeseen or urgent challenges to the nation. INDIA CONST. art. 123, $\S 1$. See generally M.P. JAIN, INDIAN CONSTITUTIONAL LAW (5th ed. 2003) (photo. reprint 2007).

222. The Prevention of Terrorism Act, No. 15 of 2002, supra note 209.

223. Kumar, supra note 220, at 196.

224. Kalhan et al., supra note 204, at 152. 
discourse within the United States in response to the PATRIOT Act, as well as the legal policy developed by the U.S. executive branch.

POTA became a driving issue in the 2004 parliamentary election. The Congress Party, then a minority party, ran on the promise to repeal POTA because of the law's enabling of abuses of human rights and civil liberties. $^{225}$ When the Congress Party won the 2004 parliamentary elections, POTA was repealed almost immediately. ${ }^{226}$

No secret law exists in terms of Indian antiterrorism policies; instead, they are generated with a significant level of publicity and public accountability. ${ }^{227}$ This publicity led to public and parliamentary support for POTA in 2002; that same publicity and public accounting led to the repeal of the Act in 2004. The content of antiterror policies is likely a reflection of the law, politics, culture, and history of a nation. Transparency and public accountability, however, demonstrate that nations are able to maintain national security programs without operating under undue secrecy. ${ }^{228}$

b. Israel

Israel has dealt with serious national security issues since its founding in 1948, with scores of people dying each year in various types of attacks, including suicide bombings, car bombs, and kidnappings. ${ }^{229}$

Israel's antiterrorism efforts, including the techniques used by Israel's General Security Service in interrogating detainees suspected of terrorist activities, are authorized broadly by Article 2(1) of the Criminal Procedure Statute and the government's general and residual powers under Article 40 of the Basic Law (Government). ${ }^{230}$

225. Id. at 152,190

226. The Prevention of Terrorism (Repeal) Act, No. 26 of 2004, available at http://indiacode. nic.in/.

227. See also The Right to Information Act, No. 22 of 2005, available at http://indiacode.nic.in/. (containing provisions similar to FOIA, including an exemption for a deliberative privilege, but not for adopted policies).

228. Although a number of acts of terrorism have occurred in India in the last several years, no credible argument has been made that the publication of India's legal policies surrounding national security is one of the bases for those attacks.

229. HCJ 5100/94 Pub. Comm. Against Torture in Israel v. Israel [1999] IsrSC 53(4) 817, ๆ 1 ("The State of Israel has been engaged in an unceasing struggle for both its very existence and security, from the day of its founding."); Stephen J. Schulhofer, Checks and Balances in Wartime: American, British and Israeli Experiences, 102 MICH. L. REV. 1906, 1918-19 (2004).

230. HCJ 5100/94 Pub. Comm. Against Torture in Israel v. Israel [1999] IsrSC 53(4) 817, $\uparrow 15$. 
The legal treatment of specific interrogation techniques used by the General Security Services is fundamentally different than how OLC memoranda treat the same issue. The authority of the General Security Service to employ certain interrogation techniques was examined by the Israeli Commission of Inquiry, ${ }^{231}$ which concluded in 1995 that the General Security Service had the authority to interrogate suspects using some physical techniques, ${ }^{232}$ and established the availability of a post factum defense of "necessity" for interrogators who engaged in what would otherwise be considered criminal actions. ${ }^{233}$

The General Security Service interpreted the necessity defense broadly; like the Bybee and Yoo Memoranda, the necessity defense was interpreted internally such that interrogators were given broad legal comfort that they could not be prosecuted for torturing terrorism suspects so long as they were doing so in an effort to preserve national security. ${ }^{234}$ But unlike the Bybee and Yoo Memoranda, this interpretation of the necessity defense was not kept secret from the public, courts, or the detainees themselves.

In Public Committee Against Torture in Israel v. Government of Israel, ${ }^{235}$ human rights groups and individual detainees challenged the blanket reading of the necessity defense based on rule of law and human rights concerns. The court-with some reservations given Israel's national security issues - unanimously held that broad legal comfort to protect interrogators who torture suspects ${ }^{236}$ was unacceptable under Israeli Basic Law. ${ }^{237}$

231. The Commission of Inquiry, which undertakes investigations of government actions, was convened under the authority of the Commission of Inquiry Statute (1968). Id. 916.

232. The techniques at issue included harsh shaking, which, in one instance, led to the death of the detainee; prolonged detention in stress positions; exposure to extreme temperatures; and covering the detainee's head with a vomit-covered hood. Id. ๆๆ 8-13.

233. Id. ๆฯ $2,15,19$.

234. Id. ๆศ $8,15-17$.

235. Id.

236. The Israeli Penal Code (1977) prohibits the use of force or violence against a person for the purpose of extorting from him a confession to an offense or information relating to an offense. Further, Israel has signed and ratified the Convention against Torture and Other Cruel, Inhuman or Degrading Treatment or Punishment. See Convention Against Torture and Other Cruel, Inhuman or Degrading Treatment or Punishment, Dec. 10, 1984, 1465 U.N.T.S. 85.

237. HCJ 5100/94 Pub. Comm. Against Torture in Israel v. Israel [1999] IsrSC 53(4) 817. The court struggled with several national priorities:

We are aware that this decision does not ease dealing with that harsh reality [of Israel's security issues]. This is the destiny of democracy, as not all means are acceptable to it, and not all practices employed by its enemies are open before it. Although a democracy must often fight with one hand tied behind its back, it nonetheless has the upper hand. Preserving the Rule of Law and recognition of an individual's liberty constitutes an important component in its understanding of security. 
The High Court, however, affirmed the availability of a necessity defense for individual interrogators being prosecuted for using such techniques during a perceived national security emergency, but rejected the argument put forth by the Israeli government, which parallels the Bybee and Yoo Memoranda, that blanket immunity ought to apply to the interrogators' actions. ${ }^{238}$

The Public Committee Against Torture decision illustrates how Israel navigated the tension between adhering to the rule of law and maximizing national security efforts, particularly with respect to making public the legal policies and parameters under which the General Security Service interrogators were acting. As in the case of India, Israel's legal policy vis-à-vis national security is developed by numerous bodies, ${ }^{239}$ justiciable, ${ }^{240}$ and open to public scrutiny. ${ }^{241}$

\section{c. United Kingdom}

The United Kingdom has dealt with significant internal and external threats to national security for many decades. A central influence on the

Id. \ 39; see also Israel Supreme Court Bans Interrogation Abuse of Palestinians, CNN.COM, Sept. 6, 1999, http://www.cnn.com/WORLD/meast/9909/06/israel.torture ("Setting a landmark in Israel's decades-old conflict between democracy and security, between respecting human rights and protecting citizens from terrorism, the Supreme Court on Monday banned the use of torture in investigations.").

238. HCJ 5100/94, Pub. Comm. Against Torture in Israel v. Israel [1999] IsrSC 53(4) 817, 938.

239. Decisions of the Israeli Attorney General in terms of legal policy or prosecution of the law, are judicially reviewable. See HCJ 935/89 Ganor v. Attorney General, 44(2) P.D. 485. The Israeli Supreme Court stated:

In a country ruled by law, where the rule of law governs, there is no justification for using special criteria to assess the validity of the discretion of the person who heads the public prosecution service. Note that this conclusion does not mean replacing the discretion of the Attorney General with the discretion of the court. This conclusion does not mean invalidating a "wrong" decision of the Attorney General — that is, one in which he chooses an undesirable but lawful decision. This conclusion means only that all governmental actors are equal in the eyes of the law.

Id.

240. Aharon Barak, Foreword: A Judge on Judging: The Role of a Supreme Court in a Democracy, 116 HARV. L. REV. 16, 153 (2002) (noting that any complaint against the executive branch and its actions is considered justiciable by the Israeli Supreme Court, regardless of the standing of the complainant); see also Schulhofer, supra note 229, at 1923 (noting that the Israeli Supreme Court "dismantled various doctrinal barriers to judicial review, such as standing and justiciability" in the 1990s). Schulhofer also notes that Israeli government and military leaders seem to accept the judicial safeguards that have been put into place to modify the conduct of the administration. Id. at 1931 .

241. Justice Ruth Bader Ginsburg lauded the Israeli decision in 2007, noting that "courts in Israel have adhered to basic fairness and due process even dealing with people who would terminate the existence of the state of Israel." Jonathan Ringel, Ginsburg Notes Israel Judges' Ban on Torture, FULTON COUNTY DAILY REP., Oct. 23, 2007, http://www.law.com/jsp/article.jsp?id=119304381 9114. 
development of the UK's modern national security regime was the violent conflicts in Northern Ireland, known as "The Troubles," which escalated in the late $1960 \mathrm{~s}^{242}$ and were largely resolved only in 1998 with the signing of the Belfast Agreement. ${ }^{243}$ During The Troubles, almost 3000 people were killed and over 30,000 were seriously injured. ${ }^{244}$

More recently, the United Kingdom has been confronted with international terrorist threats, including an attack on the London mass transit system in July 2005 which killed 56 people including the attackers, and injured over 700 others. ${ }^{245}$

UK law has vacillated in terms of trying to maintain a balance among the interests of national security, civil rights and liberties, and the rule of law. Complicating matters is that the United Kingdom is under the jurisdiction of the European Court of Human Rights (ECHR), and that detainees have the right to appeal domestic legislation and judicial decisions to the ECHR. ${ }^{246}$

As in India, Israel, and the United States, the British Prime Minister is endowed with war-making power as a legacy of a historical Crown prerogative; ${ }^{247}$ nevertheless, he or she almost always seeks authorization of Parliament to act. ${ }^{248}$ Additionally, UK law and constitutional norms require that emergency powers be exercised in a legal framework involving Parliament and the courts, ${ }^{249}$ a striking contrast to the Bush administration's vision of wartime decision-making as solely within the purview of the President. ${ }^{250}$

242. Peter Taylor, Loyalists: War and Peace in Northern Ireland 59-60 (1999).

243. Agreement Reached in the Multi-Party Negotiations, Apr. 10, 1998, reprinted in 37 INT'L LEGAL MATERIALS 751 (1998).

244. Schulhofer, supra note 229, at 1933.

245. RePORT OF THE OfFICIAL ACCOUNT OF THE BOMBINGS IN LONDON ON 7 JULY 2005, 2006, H.C. 1087 , at 2.

246. Schulhofer, supra note 229 , at 1943 .

247. Paul Bowers, Parliament AND the USe of Force (2003), available at http:// www.parliament.uk/documents/upload/snia-01218.pdf.

248. Martinez, supra note 88, at 2491. Prime Minister Tony Blair attempted to thwart parliamentary efforts to require parliamentary permission before the Prime Minister could engage in any military actions. Matthew Tempest, Government Kills Short's War Bill, GuARDIAN, Oct. 21, 2005, http://www.guardian.co.uk/politics/2005/oct/21/iraq.iraq.

249. Martinez, supra note 88, at 2499 (addressing the cooperation among the Prime Minister, Parliament and the judicial system in dealing with the ramifications of an emergency situation); see CLINTON L. Rossiter, CONSTITUTIONAL DiCTATORSHIP: CRISIS GOVERNMENT IN THE MODERN DEMOCRACIES 185-89 (1948).

250. See A (FC) \& Others (FC) v. Sec'y of State for the Home Dep't [2005] UKHL 71, [12] (noting that although the Crown had historically used torture without legislative or judicial permission, such powers were rejected with the move toward parliamentary supremacy in the late1600s); Martinez, supra note 88, at 2495. 
The Prime Minister exerts significant control over the parliament by virtue of being able to set the legislative agenda for the House of Commons, and his or her power is commensurate with his or her ability to exercise discipline over Members of Parliament from the same party. ${ }^{251}$

The mandatory involvement of the legislature ${ }^{252}$ has ensured that executive branch legal policy does not unilaterally determine how national security interests are going to be balanced with constitutional constraints. Instead, the role of Parliament has forced the Prime Minister to pass legislation in order to deal with particular situations in the war on terror; ${ }^{253}$ for example, in November 2005, former Prime Minister Tony Blair was unable to pass legislation that would allow the government to detain terrorism suspects for up to ninety days without being charged because the House of Commons, led by Blair's own Labour Party, voted down the proposed legislation. ${ }^{254}$

Further, the judicial check on executive exercise of national security powers is a robust one: judicial review is available for all nationalsecurity-related legal policy, even in times of war, and including the treatment of individual detainees. ${ }^{255}$ The 2004 decision of $A$ v. Secretary of State for the Home Department, ${ }^{256}$ illustrated that British courts will act decisively to counteract national security laws - in that case, the Anti-Terrorism, Crime and Security Act, 2001 Part IV-if they deem it to be disproportionate and discriminatory under ECHR standards. ${ }^{257}$

251. See Martinez, supra note 88, at 2489; Poguntke \& Webb, supra note 88, at 26, 32-33.

252. Canada has followed international best practices in establishing an even more powerful legislative oversight mechanism in order to increase accountability: the creation of a National Security Committee of Parliamentarians that would have full access to classified national security information. See Kent Roach, Must We Trade Rights for Security? The Choice Between Smart, Harsh, or Proportionate Security Strategies in Canada and Britain, 27 CARDOZO L. REV. 2151, 2169-70 (noting that in April 2005, the Canadian government accepted that such a committee should review the "ability of departments and agencies engaged in security and intelligence activities to fulfill their responsibilities,' including identifying 'required ongoing improvements to the effectiveness of Canada's national security system"' (quoting Press Release, Office of the Deputy Prime Minister \& Minister of Pub. Safety \& Emergency Preparedness, Model for National Security Committee of Parliamentarians (Apr. 4, 2005), available at http://www.psepc-sppcc.gc.ca/media/ nr/2005/nr20050404-1-en.asp)).

253. Schulhofer, supra note 229, at 1936-39 (noting Parliament's central role in developing legal policy on national security matters).

254. See Martinez, supra note 88, at 2499; Ed Johnson, Great Britain: Parliament Rejects Crucial Blair Antiterrorism Bill, MiAMI HeRALD, Nov. 10, 2005, at A15.

255. See Schulhofer, supra note 229, at 1940-43; see also Roach, supra note 252, at 2171.

256. [2004] UKHL 56, [2005] 2 A.C. 68.

257. See Alexandra Chirinos, Finding the Balance Between Liberty and Security: The Lords' Decision on Britain's Anti-Terrorism Act, 18 HARV. HUM. RTS. J. 265, 267 (2005) (noting the legislation in question had been reviewed and criticized by Parliament's Joint Committee on Human Rights and the Privy Counsellor Review Committee prior to being heard in court). 
Finally, UK accountability on national security law and policy is bolstered by a series of independent reviews in which a member of the House of Lords was granted the necessary security clearance and a mandate to make independent reports on the operation of the Terrorism Act, 2000, and the Prevention of Terrorism Act, 2005. ${ }^{258}$

Of course, valid questions exist as to the overall effectiveness of the national security policies in these countries as compared to U.S. policies, ${ }^{259}$ and there is always the possibility that despite our beliefthrough court decisions, governmental statements, and legislative oversight - that nations are adhering to the rule of law, those nations might be secretly developing contrary national security policies. However, if such secret policy exists in other countries, there is no indication that those policies would provide legal comfort against future prosecution. Even this limited overview of the antiterror legal rubric in three nations facing significant threats to national security suggests that in terms of process, transparency, and accountability to safeguard civil rights, the reliance in the United States on secret law might be singular. ${ }^{260}$

\section{B. Unitary Executive Theory Justifying Non-Disclosure}

The second prong ${ }^{261}$ of the administration's justification turns on a unilateralist reading ${ }^{262}$ of the unitary executive theory: the theory, evident

258. Roach, supra note 252, at 2171 (noting the need for such a measure to ensure against "[w]idespread public suspicion about national security activities [that] could eventually compromise the effectiveness of security activities").

259. E.g., Somini Sengupta, Terrorist Attacks Unsettling India, N.Y. TIMES.COM, July 29, 2008, http://www.nytimes.com/2008/07/29/world/asia/29india.html?hp (reporting on the number of Indian fatalities due to terrorism in recent years); Emily Wax, Organized Blasts Hit Tech Hub of India, WASH. POST.COM, July 25, 2008, http://www.washingtonpost.com/wp-dyn/content/article/2008/07/ 25/AR2008072501191.html?hpid=topnews (noting fatal bombings in the cities of Jaipur and Bangalore in 2008).

260. Many valid objections based on human rights grounds have been levied against the substance of the antiterrorism policies in India, Israel, and the United Kingdom, but are beyond the scope of this paper.

261. The administration has also, on occasion, put forth a secrecy justification based on attorneyclient privilege. Interrogation Rules, supra note 170 ("As an attorney I am bound to honor the confidential and privileged nature of my work for the Department of Justice .... ."); Jordan \& Hess, supra note 152 (discussing Attorney General Mukasey's refusal to disclose a 2001 OLC memorandum on interrogation techniques based on attorney-client privilege).

262. Yoo and Addington promoted a unilateralist reading. See supra note 122 and accompanying text. This reading is distinguishable from a more modest reading of the unitary executive theory, which argues the unconstitutionality of insulating administrative departments from the President's control, based on the President's removal power. See, e.g., Saikrishna Prakash, New Light on the Decision of 1789, 91 CORNELL L. REV. 1021, 1068-70 (2006) (arguing that the President's inherent executive power allows him to have control over all executive branch 
in numerous OLC memoranda issued during the Bush administration, that the President alone has the authority to decide how the administration will fulfill its constitutional obligations. ${ }^{263}$ This view is particularly evident in the Bybee and Yoo Memoranda, which specifically exclude Congress or any other group outside of the administration from influencing the President's decision-making on national security matters: "Congress may no more regulate the President's ability to detain and interrogate enemy combatants than it may regulate his ability to direct troop movements on the battlefield." 264

Numerous presidential signing statements further illustrate the administration's rejection of the authority of Congress to influence-let alone regulate - the parameters of the war on terror, and the administration's belief that Congress has no constitutional right even to understand the details of executive branch legal policy. ${ }^{265}$ The signing statements issued by the Bush administration often evidence the intent to fundamentally change the nature of the legislation itself, particularly with regard to what information related to antiterror activity Congress is entitled. $^{266}$ Notably, many of the signing statements issued by President George W. Bush object to certain provisions of the legislation based on the multiple grounds of unitary executive theory, national security, and separation of powers more generally. ${ }^{267}$

subordinates, including the Attorney General); see also Bowsher v. Synar, 478 U.S. 714, 736 (1986) (affirming President's unilateral removal power); Myers v. United States, 272 U.S. 52, 163-64 (1926) (same). But see Morrison v. Olson, 487 U.S. 654 (1988) (affirming the constitutionality of the independent counsel statute despite the lack of presidential control over the independent counsel).

263. See, e.g., Bybee Memorandum, supra note 55; Yoo Memorandum, supra note 69. Although several of these memoranda deal with U.S. conduct on national security issues, their scope may allow for purely domestic application in a non-national security context as well. See GoldSMith, supra note 8, at 97 (recalling that Yoo asserted that all military power vests in the President, a derivation of executive power from the Crown prerogative of the English monarchs); Balkin \& Levinson, supra note 4, at 499-500; see also James Risen \& Eric Lichtblau, Bush Lets U.S. Spy on Callers Without Courts, N.Y. TIMES, Dec. 16, 2005, at A1.

264. Bybee Memorandum, supra note 55, at 35.

265. Cohen, supra note 176 (noting that the Government Accountability Office issued a report concluding that in nearly one-third of the cases it examined, after President Bush issued a signing statement, his administration did not implement the legislation as written).

266. E.g., Presidential Statement on Signing the Intelligence Authorization Act for Fiscal Year 2002, 37 WeEKLY COMP. PRES. DOC. 1834 (Dec. 28, 2001) (stating that the legislated requirement that the President, under the rubric of the National Security Act of 1974, report in writing to congressional intelligence committees violated the President's constitutional authority to act in a way to protect foreign relations or national security).

267. E.g., Presidential Statement on Signing the Consolidated Appropriations Resolution 2003, 39 WeEkLY COMP. PRES. DOC. 225 (Feb. 20, 2003) (objecting to numerous provisions based on unitary executive, national security, and separation of powers grounds); Presidential Statement on Signing the 21st Century Department of Justice Appropriations Authorization Act, 38 WeEKLY COMP. PRES. DOC. 1971 (Nov. 4, 2002) (objecting to numerous provisions based on unitary 
When national security concerns are peeled away, a continued and consistent priority of the Bush administration ${ }^{268}$ appears to have been to leverage the power that comes with having a complete understanding of U.S. national security policy, when Congress - tasked with oversight of the executive branch-patently does not. ${ }^{26}$

The Bush administration's reliance on textual arguments ${ }^{270}$ based in the Commander-in-Chief Clause and the Vesting Clause ${ }^{271}$ of the Constitution that the Executive branch alone has jurisdiction over warrelated decisions is subject to numerous critiques. ${ }^{272}$

First, there is little evidence that the framers of the Constitution concurred with each other as to the nature and extent of an inherent executive power. ${ }^{273}$ The framers of the Constitution and early administrations illustrate an emphasis on pragmatic approaches to powersharing; this is particularly true with regard to the Attorney General, an office adopted from the British and state colonial governments, whose

executive, national security, and separation of powers grounds); Presidential Statement on Signing the Foreign Relations Authorization Act, 38 WeEKLy COM. PrES. Doc. 1658 (Sept. 29, 2002) (same). See generally Neil Kinkopf \& Peter Shane, Am. Constitution Soc'y for Law \& Policy, Index of Presidential Signing Statements: 2001-2007 (2007), available at http://www.acslaw.org/files/ Signing\%20Statement \%20Chart\%20-\%20Neil\%20Kinkopf\%20and\%20Peter\%20Shane.pdf (supplementing the signing statements and indexing according to statute name, provision objected to, and reason for objection).

268. Although many administration critics believed that Attorney General Mukasey would represent a softening of the administration's reliance on unitary executive theory, Mukasey himself has relied on it. See Oversight Hearing Transcript, supra note 7, at 37 (describing Mukasey's refusal to discuss the legality of the U.S. interrogation program with the Senate due to the fact that the Senate's questions were inappropriate and unanswerable on separation of powers grounds); see also id. at 19 (describing Mukasey's acknowledgment that the administration's objection to the whistleblower provisions in S. 274 were not based on concerns about national security issues, but rather on the right of the President to operate in a manner unfettered by Congress on national security matters).

269. See Mark J. Rozell, Executive Privilege: The Dilemma of Secrecy AND DEMOCRATIC ACCOUNTABILITY 43-46, 112-13 (1994); Kitrosser, supra note 5, at 1050, 1058-59, 1065; Peter M. Shane, Negotiating for Knowledge: Administrative Responses to Congressional Demands for Information, 44 ADMIN. L. REV. 197, 199-200 (1992).

270. See John C. Yoo, The Continuation of Politics by Other Means: The Original Understanding of War Powers, 84 CAL. L. REV. 167 (1996) (making a textualist argument that courts have no role in national security matters and that Congress's role is limited to its spending power and the impeachment process).

271. U.S. CONST. art. II, $\S 1$, cl. 1.

272. See, e.g., Wartime Executive Power, supra note 148 (citing The Prize Cases, 67 U.S. (2 Black) 635, 668 (1803) (arguing that the President has whatever authority is necessary to fulfill the "solemn duty" of national security)); Curtis A. Bradley \& Martin S. Flaherty, Executive Power Essentialism and Foreign Affairs, 102 MICH. L. REV. 545, 688 (2004) (describing lack of historical basis for inherent executive power argument); Johnsen, supra note 6, at 1560.

273. Compare RAKOVE, supra note 185, at 244-87 (describing debates about executive power at time of ratification) with Julian $\mathrm{Ku} \&$ John Yoo, Hamdan v. Rumsfeld: The Functional Case for Foreign Affairs Deference to the Executive Branch, 23 CONST. COMMENT. 179 (2006) (arguing for more deference to be given to executive interpretations of foreign affairs laws). 
goal is to provide counsel to both the President and Congress. ${ }^{274}$ Even if the framers of the Constitution did agree on these points when the Constitution was being drafted, the Department of Justice-established following the Civil War as a means for the federal government to enforce the post-Civil War constitutional amendments ${ }^{275}$ _ did not exist when the Constitution was drafted, thus making an Article II defense of Justice Department activities weak and convoluted.

Second, the framers expressed a tremendous interest in establishing a system of checks and balances to counteract any one branch maintaining a concentration of power. ${ }^{276}$ Even Alexander Hamilton, a framer of the Constitution and an ardent proponent of presidential power, noted that in a republican government, the President would have to defer to the legislative will much of the time. ${ }^{277}$ Hamilton also argued that ease of oversight was one of the benefits of an executive branch headed by an individual President, who "will be more narrowly watched and more readily suspected." 278

Third, this unilateralist unitary executive theory inappropriately discounts Congress's constitutionally granted war powers, including Congress's right to regulate captures during war, ${ }^{279}$ and Congress's ability to exercise oversight of the Executive, ${ }^{280}$ even with regard to matters of national security. ${ }^{281}$

Further, it ignores the structure set discussed by Justice Jackson in Youngstown Sheet \& Tube Co. v. Sawyer, ${ }^{282}$ which acknowledges Congress's role in oversight, including oversight in the areas of

274. BAKER, supra note 6, at 37-38.

275. RAKOVE, supra note 185 , at 344-56.

276. E.g., The Federalist No. 51 (James Madison) (arguing that the checks and balances among the branches of government are such that "[a]mbition [would] counteract ambition").

277. The Federalist No. 71 (Alexander Hamilton); see also Setty, supra note 113, at 281-87 (discussing the expectations of the framers of the Constitution regarding executive and legislative power dynamics).

278. THE FEDERALIST NO. 70 (Alexander Hamilton).

279. U.S. CONST. art. I, $\S 8$, cl. 11.

280. U.S. CONST. art. I, $\S 5$, cl. 2. The congressional obligation to conduct oversight of the executive branch is an implied constitutional power, and has been recognized and affirmed by the U.S. Supreme Court on numerous occasions. See Watkins v. United States, 354 U.S. 178, 187 (1957) ("[The] power of the Congress to conduct investigations is inherent in the legislative process. That power is broad."); McGrain v. Daugherty, 273 U.S. 135, 174 (1927) (stating that "the power of inquiry - with process to enforce it-is an essential and appropriate auxiliary to the legislative function").

281. Barron \& Lederman, supra note 32, at 691-92 (noting that "there is surprisingly little historical evidence supporting the notion that the conduct of military campaigns is beyond legislative control").

282. 343 U.S. 579 (1952). 
intelligence and national security. ${ }^{283}$ Justice Jackson noted that unilateral executive power is at its "lowest ebb" when the President "takes measures incompatible with the expressed or implied will of Congress." 284 This assessment of presidential power is long-standing and consistent; from the earliest years of U.S. history, courts have rejected the notion that the President can ignore duly enacted statutes. ${ }^{285}$

A unitary executive theory that holds that executive branch interpretation of the Constitution has primacy over the interpretations made by the Judiciary and Congress lacks historical and legal bases. ${ }^{286}$ In earlier administrations - both Republican and Democratic - the OLC consistently found that the President must subordinate his actions to duly enacted statutes. ${ }^{287}$

Fourth, Congress has mandated disclosure of executive branch decision-making in other contexts. Provisions of the Administrative Procedure Act and the Freedom of Information Act make clear that an administration cannot conduct itself according to a system of "secret law."288 Regarding the FOIA requirements, the Court in NLRB v. Sears, Roebuck \& Co. made clear when mandating disclosure:

[I]ndexing of "final opinions," "statements of policy and interpretations which have been adopted by the agency," and "instructions to staff that affect a member of the public," represents a strong congressional aversion to "secret (agency) law," and represents an affirmative congressional purpose to require disclosure of documents which have "the force and effect of law.",

Nonetheless, a President who subscribes to a robust view of the unitary executive theory may dispute legislative efforts to mandate disclosure of executive branch legal policy. ${ }^{290}$ This dispute may manifest

283. Id. at 634-55 (Jackson, J., concurring); see also Oversight Hearing Transcript, supra note 7 , at 5 (remarks of Sen. Arlen Specter).

284. Youngstown, 343 U.S. at 637 .

285. See, e.g., Little v. Barreme, 6 U.S. 170, 170 (1804); see also Interrogation Rules, Schroeder Statement, supra note 58, at 5;

286. See United States v. Nixon, 418 U.S. 683, $703-07$ (1974); Powell, supra note 50, at 1315 (arguing that executive branch avoidance should never be used in the context of the separation of powers or when dealing with the President's powers under the Commander-in-Chief Clause); Charlie Savage, Bush Challenges Hundreds of Laws; President Cites Powers of His Office, Boston GloBE, Apr. 30, 2006, at A1; see also Oversight Hearing Transcript, supra note 7, at 15 (describing Attorney General Mukasey's acknowledgement of the history of executive avoidance of Congress's oversight).

287. Interrogation Rules, Schroeder Statement, supra note 58, at 4-5.

288. See, e.g., 5 U.S.C. $\$ 552(a)(2)(2007)$

289. 421 U.S. 132, 153 (1975) (citations omitted).

290. See Balkin \& Levinson, supra note 4, at 499 ("The OLC, and the DOJ more generally, have 
itself in a refusal to comply with the legislated disclosure requirements based on the theory of constitutional avoidance. ${ }^{291}$

If Congress attempts to mandate information disclosure related to national security, the President may choose to "avoid" a potential constitutional conflict between the Article I powers of Congress and the Article II powers of the President, thus refusing to enforce legislation mandating the sharing of information. ${ }^{292}$ Congress took limited steps in late 2008 to engage in meaningful oversight of the OLC by introducing legislation that would mandate disclosure of those OLC opinions in which avoidance is used as a basis for non-compliance with a statutory provision or treaty obligation. ${ }^{293}$

been crucial in creating and providing constitutional interpretations justifying the President's robust assertions of Article II power to disregard congressional statutes that he believes hamper his inherent authority as Commander-in-Chief."). It is also questionable whether such a check would be effective in practice, considering the historical pattern of Congress not exercising its oversight function during wartime. The passage by Congress of the Military Commissions Act of 2006 illustrates Congress's deference to the President during wartime. Pub. L. No. 109-366, 120 Stat. 2600 (current version at 10 U.S.C. $\$ 9486$ (b) (2006)); see Johnsen, supra note 6, at 1575; see also Martinez, supra note 88, at 2491 ("Proponents of the inherent executive power thesis argue that the power to wage war is intrinsically 'executive' in nature."). Such an effect is also compounded in times of unified government, when Congress and the President are of the same political party. See Levinson \& Pildes, supra note 168, at 2314-15.

291. Constitutional avoidance in the executive context has been used to mean that the President can "avoid" a constitutional dispute by asserting his own view of his constitutional obligations any time the actions of another branch make an incursion onto the constitutional right of the executive to exert its decision-making primacy in certain areas, such as in the conduct of war. See Morrison, supra note 50, at 1218-19 (critiquing the OLC's use of avoidance to assert more presidential power than is granted under law). Congress attempted to address the question of constitutional avoidance in 2002 through appropriations legislation that included a provision mandating notification to Congress whenever the executive branch chooses not to enforce a law as written. See The 21st Century Department of Justice Appropriations Authorization Act, § 202, Pub. L. No. 107-273, 28 U.S.C. $§ 530 D$ (2002). Unfortunately, the administration appears to have engaged in "metaavoidance" by refusing to comply with the congressional notification requirement in the Act. See, e.g., President's Statement on Signing the 21st Century Department of Justice Appropriations Authorization Act, 38 WEEKLY COMP. PRES. DOCS. 1971 (Nov. 2, 2002) ("[Section 530D] purports to impose on the executive branch substantial obligations for reporting to the Congress activities of the Department of Justice involving challenges to or nonenforcement of law that conflicts with the Constitution. The executive branch shall construe section 530D . . in a manner consistent with the constitutional authorities of the President to supervise the unitary executive branch ...."); Letter from Michael B. Mukasey, U.S. Att'y Gen., to Harry Reid, Senate Majority Leader 1-6 (Nov. 14, 2008), available at http://www.usdoj.gov/olc/2008/olc-reporting-act.pdf (encouraging the use of constitutional avoidance to sidestep a reporting requirement regarding OLC opinions).

292. See Johnsen, supra note 6, at 1563; Morrison, supra note 50, at 1253-58. Members of Congress, acknowledging the ineffectiveness of congressional oversight in the face of the heightened use of executive privilege and constitutional avoidance, have voiced the belief that the courts are the last safeguards of the separation of powers. Oversight Hearing Transcript, supra note 7, at 5, 1617. Sen. Specter has objected to this meta-use of constitutional avoidance, noting that even if enforcement of a statute is "avoided" by the administration, that avoidance needs to be reported to the appropriate committee in the Senate and House of Representatives. Id. at 15.

293. See OLC Reporting Act of 2008, S. 3501, 110th Cong. (2008) (as reported by S. Comm. on the Judiciary, Sept. 16, 2008) (introduced by Sens. Feingold and Feinstein); Office of Legal Counsel 
Further, an administration may argue that the question of mandatory disclosure is a political one, and therefore not justiciable. ${ }^{294}$ However, courts have made clear that although "decision-making in the fields of foreign policy and national security is textually committed to the political branches of government," 295 questions that pertain only to the disclosure of policies related to national security matters and not to the substance of those policies do not implicate the political question doctrine and are, therefore, justiciable. ${ }^{296}$

Recent court decisions have further shown that the judiciary sees some limits on the President's use of the unitary executive theory and the expansion of presidential power under the Commander-in-Chief Clause, ${ }^{297}$ even in times of war. ${ }^{298}$ For example, Hamdan v. Rumsfeld squarely rejected the assertion of the Yoo Memorandum that "Congress cannot exercise its authority to make rules for the Armed Forces to regulate military commissions." 299 However, the Court's acquiescence to most administration claims of state secrets ${ }^{300}$ brings into serious question

Reporting Act of 2008, H.R. 6929, 110th Cong. (introduced by Rep. Miller). Both bills propose amendments to 28 U.S.C. $\S 530 \mathrm{D}$ to oblige the Attorney General to report to Congress on nonenforcement of statutes based on OLC opinions claiming constitutional avoidance based on the OLC's reading of presidential power under Article II. Such an amendment has been supported by former OLC lawyers and scholars. See Hearing on Restoring the Rule of Law: Before the Subcomm. on the Constitution of the S. Comm. of the Judiciary, 110th Cong. (2008) (statement of Walter Dellinger, Visiting Professor of Law, Harvard Law School); Trevor W. Morrison, Executive Branch Avoidance and the Need for Congressional Notification, COLUM. L. REV. SidEBAR, Feb. 15, 2007, http://www.columbialawreview.org/articles/executive-branch-avoidence-and-the-need-for-

congressional-notification. Attorney General Michael B. Mukasey counseled the use of executive branch constitutional avoidance to sidestep the reporting requirements in this legislation. Mukasey, supra note 291, at 3.

294. See, e.g., Wilson v. Libby, 535 F.3d 697, 704 (D.C. Cir. 2008).

295. Schneider v. Kissinger, 412 F.3d 190, 194 (D.C. Cir. 2005).

296. Wilson, 535 F.3d at 704.

297. U.S. CONST. art. II, § 2, cl. 1.

298. See, e.g., Hamdan v. Rumsfeld, 548 U.S. 557, 635 (2006) ("The Executive is bound to comply with the Rule of Law ...."); Hamdi v. Rumsfeld, 542 U.S. 507, 536 (2004) (plurality opinion) ("We have long since made clear that a state of war is not a blank check for the President when it comes to the rights of the Nation's citizens."); al-Marri v. Wright, 487 F.3d 160, 190-92 (4th Cir. 2007) (denying the administration's "breathtaking claim" that inherent executive power allows the President to detain people indefinitely). Congress has limited the Judiciary's ability to effect a strong check on presidential overreaching. See Military Commissions Act of 2006, 10 U.S.C. § 948a (2006).

299. Hamdan, 548 U.S. at 635 (citing Yoo Memorandum, supra note 69, at 13 n.13); Interrogation Rules, Schroeder Statement, supra note 58, at 6.

300. See generally United States v. Reynolds, 345 U.S. 1 (1953) (establishing the standard by which courts should evaluate government claims of state secrets); see also el-Masri v. United States, 479 F.3d 296 (4th Cir. 2007), cert. denied, 128 S. Ct. 373 (2007) (dismissing a claim of extraordinary rendition and gross human rights abuses based on the administration's claim of state secrets). 
the effectiveness of the courts in safeguarding checks and balances in the area of national security.

Since the Democrats took control of both houses of Congress in 2006, there has been a significant increase in oversight efforts. ${ }^{301}$ However, the Bush administration refused to comply with congressional information requests through the waning days of the Bush presidency. ${ }^{302}$ As such, mandatory disclosure of OLC opinions would put greater pressure on the administration to follow through with timely disclosure, particularly if the defensive use of the opinions would be rendered invalid without such disclosure.

Although the legislation proposed in 2008 mandating disclosure of those OLC opinions which support executive branch avoidance was a positive step, legislators should go further and mandate a broader disclosure of OLC opinions. Congress is well within its oversight powers to do so, and making a broader structural change is necessary to restore the rule of law and the standing of the United States as a nation that is a standard bearer for democratic principles. ${ }^{304}$ Eliminating the existence of secret laws and restoring the democratic principles of the application of law are two important means of doing so. As the court in Ex parte Milligan explained:

The Constitution of the United States is a law for rulers and people, equally in war and in peace, and covers with the shield of its protection all classes of men, at all times, and under all circumstances. No doctrine, involving more pernicious consequences, was ever invented by the wit of man than that any of its provisions can be suspended during any of the great exigencies of government. Such a doctrine leads directly to anarchy or despotism, but the theory of necessity on which it is based is false; for the government, within the Constitution, has all the powers granted to it, which are necessary to preserve its existence .... 305

301. See Setty, supra note 113, at $261 \mathrm{n} .70$ (discussing the desire for congressional oversight of the administration as one reason for the shift in party control of the Senate and House of Representatives in 2006).

302. Editorial, Time to Vote Contempt, N.Y. TIMES, Feb. 14, 2008, at A34 (noting Congress's failure to enforce its own subpoenas on the administration).

304. See generally Harold Hongju Koh, On American Exceptionalism, 55 StAN. L. REV. 1479 (2003) (addressing the idea that the United States is unique in its global reach for promoting democratic ideals).

305. 71 U.S. (4 Wall) 2, 120-21 (1866). 


\section{CONCLUSION}

OLC memoranda, as a general rule, should be disclosed by the administration. The politicization of the Office of Legal Counsel during the Bush administration, when combined with the predictable selfinterest of any administration in not voluntarily disclosing its own legal policies, means that institutional steps must be taken to ensure greater transparency and adherence to the rule of law. To that end, Congress should require publication of OLC-generated legal policies in order to ensure the long-term integrity of executive branch constitutional interpretation. 